\title{
On the Demise of the Early Paleogene Morozovella velascoensis Lineage: Terminal Progenesis in the Planktonic Foraminifera
}

\author{
D. CLAY KELLY* \\ Department of Geology and Geophysics, Woods Hole Oceanographic Institution, \\ Woods Hole, MA 02543 \\ TIMOTHY J. BRALOWER \\ Department of Geology, The University of North Carolina at Chapel Hill, \\ Chapel Hill, NC 25799 \\ JAMES C. ZACHOS \\ Earth Sciences Department, University of California at Santa Cruz, \\ Santa Cruz, CA 45064
}

PALAIOS, 2001, V. 16, p. 507-523

The extinction of the Morozovella velascoensis lineage, a group of planktonic foraminifera that dominated tropical assemblages for $\sim 6.3$ m.y., is investigated using an upper Paleocene/lower Eocene section from the central Pacific Ocean (ODP Site 865). Uppermost stratigraphic occurrences of the lineage consist solely of diminutive M. edgari, a species roughly half the size of its ancestor, M. velascoensis. Eigenshape analysis indicates that adult specimens of M. edgari are morphologically similar to small, presumably juvenile, forms of M. velascoensis. The overall stratigraphic succession, where the uppermost occurrences of a lineage are represented by relict populations of minute, juvenilized forms, is consistent with a process called "terminal progenesis." Various lines of evidence indicate that stress-induced size reduction foreshadowed the extinction of other planktonic foraminiferal lineages as well.

The ecological cause(s) for the extinction of ancestral $\mathrm{M}$. velascoensis is unclear. Stable isotopic evidence for a progressive deterioration of algal symbiosis was not detected. Specifically, none of the individually-analyzed shells of M. velascoensis were depleted significantly in ${ }^{13} \mathrm{C}$, nor was there a decrease in the covariance of the $\delta^{13} \mathrm{C} /$ size relationship.

Planktonic foraminiferal $\delta^{18} \mathrm{O}$ values exhibit a subtle increase over the stratigraphic interval in which the M. edgari extinction is recorded. This inferred tropical cooling appears to be correlative with terrestrial records of cooling from the North American continental interior and northwestern Europe. Thus, it is postulated that climatic variation during the earliest Eocene $(\sim 54.02 \mathrm{Ma})$ played a significant role in shaping biodiversity in the pelagic realm, sealing the doom of the declining $\mathrm{M}$. velascoensis lineage.

\footnotetext{
* Current address: Department of Geology and Geophysics, University of Wisconsin, Madison, WI 53706.
}

Copyright $\odot$ 2001, SEPM (Society for Sedimentary Geology)

\section{INTRODUCTION}

During the late nineteenth and early twentieth centuries, paleontologists commonly considered large body size and excessive skeletal ornamentation to be signs of imminent extinction. Beecher (1898) proposed that the appearance of ornate, spinose morphologies indicated the advanced stages of racial senescence; Lull (1921) referred to this form of degeneracy as "spinescence." Given this historical bias, it is unsurprising that racial senescence has been invoked (Blow, 1979) to explain the iterative evolution and extinction of ornate members of the planktonic foraminiferal genus Morozovella. The species M. velascoensis easily is distinguished from other Paleocene planktonic foraminifera owing to its relatively large size and exaggerated skeletal ornamentation (Fig. 1A-C). The last appearance datum (LAD) of a distinctive morphotype like M. velascoensis constitutes an unequivocal biostratigraphic datum, one that micropaleontologists have used to identify the Paleocene/Eocene boundary (e.g., Bolli, 1957; Stainforth et al., 1975; Blow, 1979; Boersma et al., 1987; Berggren and Miller, 1988: Berggren et al., 1995). Ironically, the biostratigraphic utility of the M. velascoensis LAD has reinforced the notion that the $M$. velascoensis clade terminated with the extinction of its nominate taxon. Thus, $M$. velascoensis has been considered the culmination of a directional evolutionary trend, and as such, a phylogenetic dead end (e.g., Bolli, 1957; Berggren, 1968, 1969; Subbotina, 1971).

Aside from its biostratigraphic significance, the extinction of $M$. velascoensis has received little attention in the literature. This is surprising because $M$. velascoensis is the root species of a diverse lineage that colonized the oceanic mixed-layer throughout the tropics and subtropics for the entirety of the late Paleocene (61.0-54.7 Ma). In fact, $M$. velascoensis is the immediate ancestor to at least four separate morozovellid species, with the evolutionary origins of two other species being linked indirectly to $M$. velascoensis (Kelly et al., 1998; Olsson et al., 1999; Premoli Silva and Bolli, 1973). Thus, the demise of M. velascoensis and its immediate line of descent constitute a milestone in 0883-1351/01/0016-0507/\$3.00 


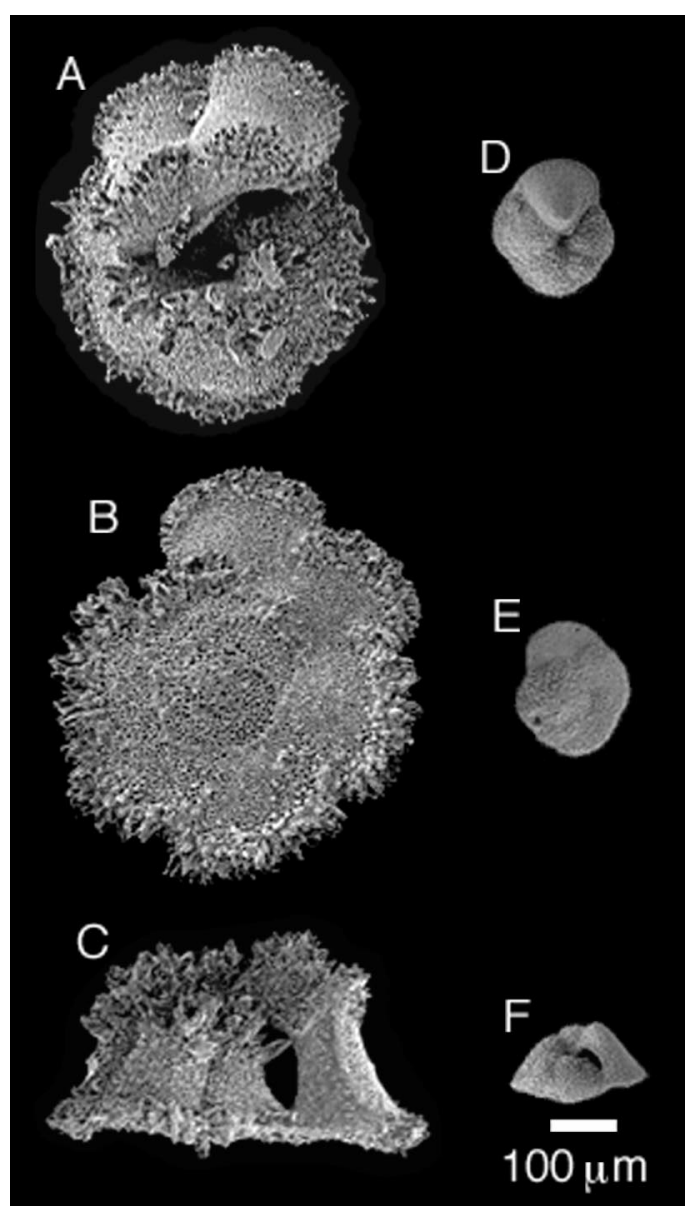

FIGURE 1-Scanning electron micrographs of two morozovellid species from the central Pacific Ocean (ODP Hole 865B). (A-C) Morozovella velascoensis $(102.35 \mathrm{~m})$ : umbilical view $(\mathrm{A})$, spiral view $(\mathrm{B})$, and edge view (C). (D-F) Morozovella edgari (95.70 m): umbilical view $(D)$, spiral view $(E)$, and edge view $(F)$.

the evolutionary history of the Early Paleogene planktonic foraminifera. Here, parallel morphometric and stable isotopic analyses, as well as scanning electron microscopy, have been employed to investigate the extinction of $M$. velascoensis and the morphological responses associated with the demise of its lineage. In doing so, background extinction in the pelagic realm can be related to ocean-climate change.

\section{A Working Phylogeny}

An alternative view of the $M$. velascoensis extinction emerged with the formal recognition of Morozovella edgari (Fig. 1D-F). In their description of the holotype, Premoli Silva and Bolli (1973) suggested that M. edgari evolved from $M$. velascoensis. At first glance, this evolutionary transition seems to represent a striking morphological transformation (see Fig. 1). The shells of both taxa are pustulate, but fully-developed morphotypes of $M$. velascoensis are excessively ornate. The pustules on $M$. velascoensis are concentrated atop the umbilical tips of the chambers (Fig. 1A), aggregated along the intercameral sutures on the dorsal side of the shell (Fig. 1B), and clustered about the shell peripheral margin forming a ragged keel
(Fig. 1C). In contrast, shells of M. edgari (Fig. 1D-F) are rather nondescript and, as noted by Premoli Silva and Bolli (1973), only about half the size of $M$. velascoesnsis.

Inspection of size-segregated populations reveals that the frequency of ornate $M$. velascoensis shells decreases in the finer size fractions $(125-250 \mu \mathrm{m})$. In fact, ornate shells are absent altogether in size fractions smaller than 125 $\mu \mathrm{m}$. The paucity of ornate forms in the smaller size fractions of samples containing large, distinctive $M$. velascoensis indicates that morphology is dependent upon shell size. Ontogenetic studies have shown that patterns of size-dependent shape variation, or allometry, are common among modern planktonic foraminifera (e.g., Bé, 1980; Sverdlove and Bé, 1985; Brummer et al., 1987).

The presence of an allometry (Fig. 2A-D) in M. velascoensis has important phylogenetic implications. Tracing this allometry through successive size fractions reveals that small shells of $M$. velascoensis (Fig. 2D) resemble $M$. edgari (Fig. 2E) in their weakly-developed keels and absence of pustulate umbilical collars. Furthermore, the shells of small $M$. velascoensis (Fig. 2B-D, left) are coiled more tightly than their larger counterparts (Fig. 2A, left). The tightly coiled spiral of smaller $M$. velascoensis shells results in a constricted umbilicus, another feature reminiscent of M. edgari (Fig. 2F, left). The gross morphological similarity between $M$. edgari and small specimens of $M$. velascoensis also can be viewed by sectioning a large, fully-developed specimen of $M$. velascoensis (Fig. 3A). In cross-section (Fig. 3B), the outline of the inner, juvenile portion of the M. velascoensis shell bears a strikingly resemblance to the edgewise profile of M. edgari (Fig. 3C).

The stratigraphic distributions of $M$. edgari and $M$. velascoensis support taxonomic differentiation of the two morphotypes. In the Caribbean Sea (DSDP Site 152), Premoli Silva and Bolli (1973) recorded the lowermost stratigraphic occurrence of $M$. edgari well above the $M$. velascoensis $\mathrm{FAD}$ and noted that populations of $M$. edgari were found some 15 meters upsection from the $M$. velascoensis LAD. Thus, according to the phylogeny of Premoli Silva and Bolli (1973), the final stages of decline in the M. velascoensis lineage are represented by diminutive M. edgari.

Toumarkine and Luterbacher (1985) retained M. velascoensis as an evolutionary dead end by assigning $M$. edgari to a separate lineage. Under their phylogenetic scheme, $M$. edgari is presumed to have evolved from $M$. aequa. The wall textures of $M$. edgari and $M$. aequa seem to support this hypothetical lineage. Pustules are distributed evenly over the shell surfaces of both $M$. edgari (Fig. 4A-B) and $M$. aequa (Fig. 4C), as opposed to being clustered about the shell extremities as on $M$. velascoensis (Fig. 4D). However, these wall textural differences are observed only when M. edgari is compared to large, fullydeveloped specimens of $M$. velascoensis. This is not the case when M. edgari is compared to small specimens of $M$. velascoensis. Like M. edgari, small specimens of $M$. velascoensis (Fig. 4E) have pustules dispersed evenly over their shells. Thus, pustules become concentrated about the shell extremities only during the later developmental stages of $M$. velascoensis. Similar size-dependent patterns of morphological and wall textural variation have been noted in other morozovellid species (e.g., Kelly et al., 1996, 1999).

Other lines of morphological evidence point toward $M$. 


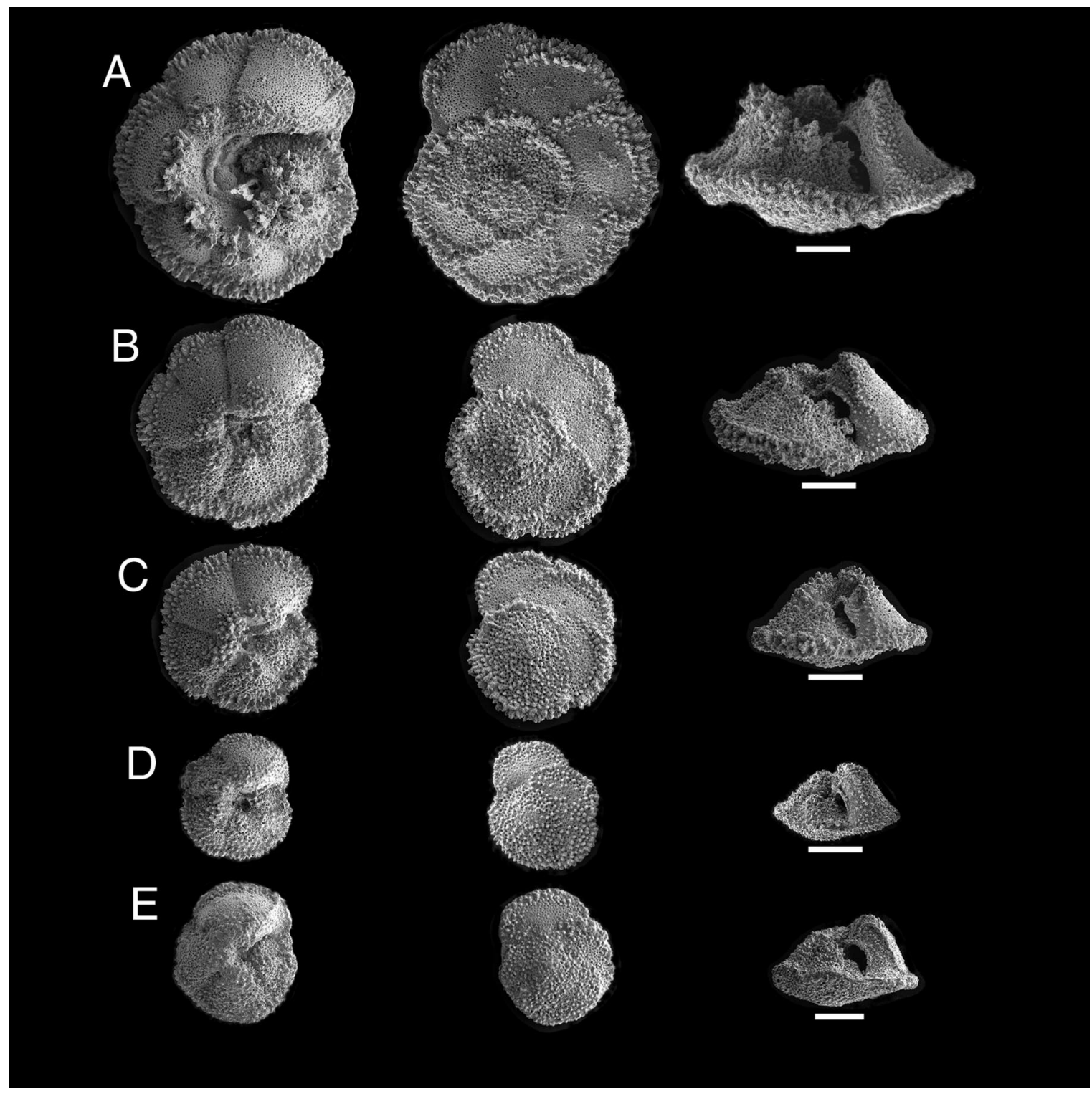

FIGURE 2-Assortment of size-segregated specimens from various locales summarizing the basic relationship between shell shape and size in $M$. velascoensis (A-D) and $M$. edgari (E). Specimen orientations are: umbilical view (left), spiral view (middle), edge view (right). All scale bars $=100 \mu \mathrm{m}$. Specimens used to illustrate M. velascoensis shape/size covariance are from late Paleocene (foram Zone P4) sediments recovered in the Indian Ocean (ODP Hole 758A, $268.60 \mathrm{~m}$ ), except large specimen (A) shown in umbilical and spiral views (foram Zone P5, ODP Hole 865B-102.35 m, central Pacific). (E) Topotype of $M$. edgari from an early Eocene (foram Zone P6a) sample that postdates the extinction of $M$. velascoensis and recovered at DSDP Site 152 (Core 3-5, 21-23 cm) in the Caribbean Sea. Also note gross morphological similarity between small-sized $M$. velascoensis (D) and M. edgari (E).

velascoensis as the ancestor of M. edgari. The equatorial outline of $M$. aequa is strongly lobulate, while it is relatively smooth in both $M$. edgari and small-sized $M$. velascoensis (see Fig. 4). Furthermore, both M. edgari and M. velascoensis coil preferentially in the sinistral direction ( 95\%), while $M$. aequa and its line of descent predominantly are coiled dextrally (see Bolli, 1957; Premoli Silva and Bolli, 1973). Norris and Nishi (2001) found similar evolutionary trends in the coiling ratios of morozovellids from the tropical Pacific (ODP Site 865). In light of these observations, it is clear that M. edgari evolved from the $M$. velascoensis group, and the phylogeny proposed by Pre- moli Silva and Bolli (1973) is favored in the present work. Thus, some of the interpretations in this report are predicated upon the derivation of M. edgari from M. velascoensis.

\section{MATERIALS AND METHODS}

The transition from Morozovella velascoensis to M. edgari is recorded in foraminiferal- nannofossil oozes recovered from Ocean Drilling Program (ODP) Site 865. This site is located atop Allison Guyot $\left(18^{\circ} 26^{\prime} \mathrm{N}, 179^{\circ} 33^{\prime} \mathrm{W}\right)$ in the Mid-Pacific Mountains (Sager et al., 1993). Paleolati- 


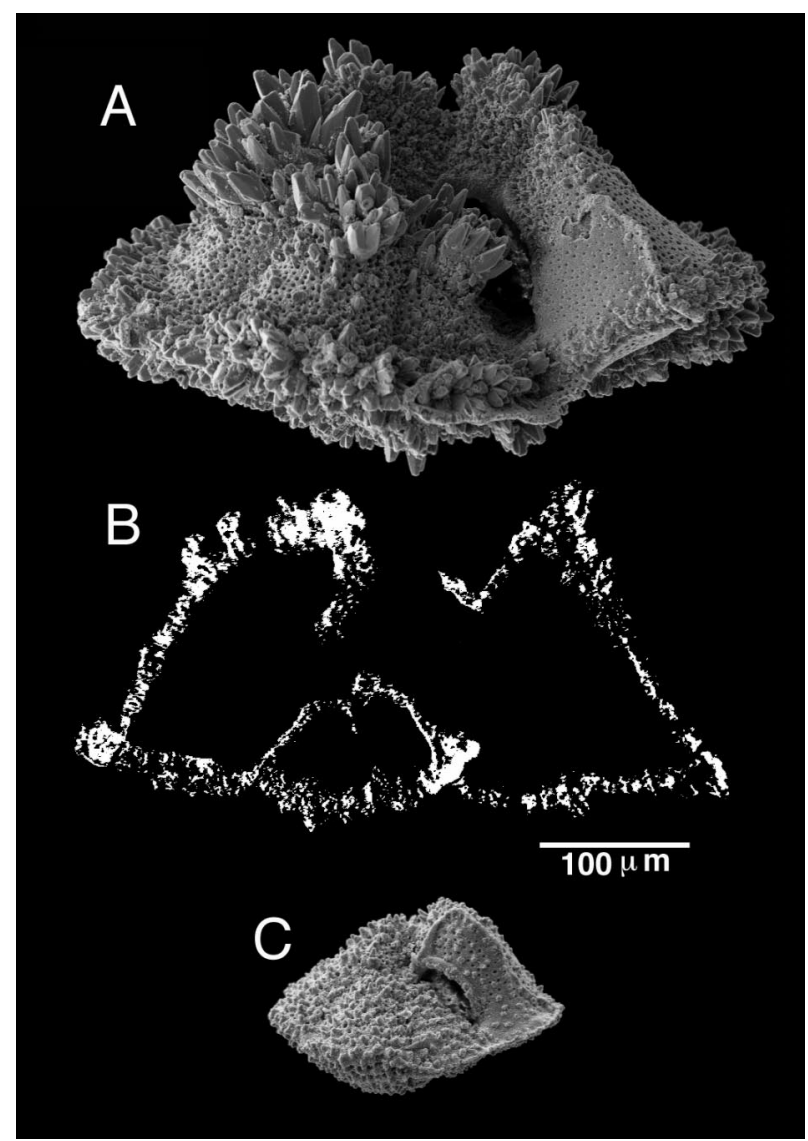

FIGURE 3-Scanning electron micrographs showing similarity between edge-wise profiles of inner, juvenile chambers of Morozovella velascoensis and adult $M$. edgari. All specimens from central Pacific (ODP Hole 865B). (A) M. velascoensis (102.35 m) in edge view; (B) backscatter electron emission image of cross-sectioned $M$. velascoensis $(102.35 \mathrm{~m})$ in edge view; (C) M. edgari $(95.70 \mathrm{~m})$ in edge view.

tude projections position the study area at approximately $5^{\circ} \mathrm{N}$ latitude during the late Paleocene (Bralower et al., 1995). Estimates based on benthic foraminiferal assemblages suggest a late Paleocene water depth between 1000-1300 m (Bralower et al., 1995). Planktonic foraminifera were extracted from the sediments by washing each sample over a $63-\mu \mathrm{m}$ sieve with $\mathrm{pH}$ buffered, deionized water.

\section{Chronologic Framework}

Various stratigraphic criteria (e.g., stable isotopes, benthic and planktonic foraminifera, and calcareous nannofossils) were used to construct a chronology for the Hole 865B study section (Table 1). The 10-meter study section (Fig. 5) is bound stratigraphically by the FADs of two calcareous nannofossil marker taxa (Bralower and Mutterlose, 1995). The lowermost chronologic datum is defined by the Discoaster multiradiatus FAD (56.20 Ma), while the uppermost datum is demarcated by the $D$. lodoensis FAD (52.85 Ma). Chronologic resolution was enhanced with the use of the M. velascoensis $\mathrm{LAD}(54.70 \mathrm{Ma})$ and the benthic foraminiferal extinction event (BFEE) that coincides with the carbon-isotope excursion (CIE) of the late Paleocene

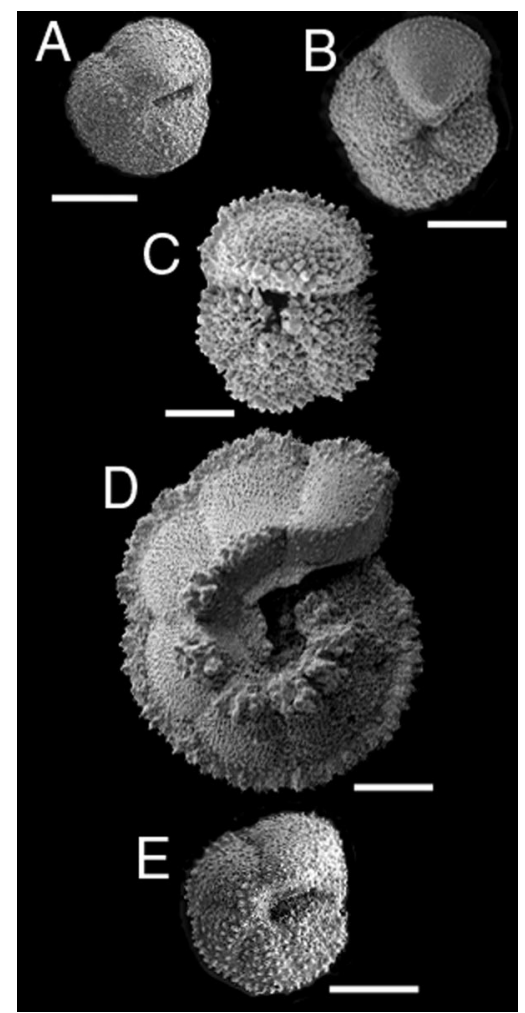

FIGURE 4-Representative specimens of Morozovella edgari (A, B), $M$. aequa $(C)$, large $M$. velascoensis $(D)$, and small $M$. velascoensis (E). Specimens of $M$. edgari from early Eocene samples (foram Zone $\mathrm{P} 6 \mathrm{a}$ ) that postdate the extinction of M. velascoensis. (A) Topotype of M. edgari from DSDP Site 152 (Core 3-5, 21-23 cm) located in the Caribbean Sea. (B) M. edgari from ODP Hole 865B (95.70 m). (C) $M$. aequa from late Paleocene (foram Zone P4) in Indian Ocean (ODP Hole 758A, $263.40 \mathrm{~m}$ ). (D) Large, adult $M$. velascoensis from late Paleocene (foram Zone P3b/P4) in Indian Ocean (ODP Hole 758A, $281.30 \mathrm{~m}$ ). (E) Small M. velascoensis from late Paleocene (foram Zone P4) of Indian Ocean (ODP Hole 758A, $268.60 \mathrm{~m}$ ). All scale bars $=100 \mu \mathrm{m}$.

thermal maximum (55.50 Ma -Thomas and Shackleton, 1995). Numerical ages for the various biostratigraphic datums were taken from Berggren et al. (1995), and age estimates for the study samples were calculated by linear interpolation between chronologic datums (Table 1). Thus, the 16 samples from the study section $(94.20-104.20 \mathrm{~m})$ encompass an interval of 1.5 my with a temporal resolution of about $100 \mathrm{ky}$ between samples.

Morphological intergradation between $M$. edgari and small-sized $M$. velascoensis is most complete during the early stages of evolutionary divergence, making placement of the $M$. edgari FAD somewhat subjective. Nevertheless, a faunal succession like that described by Premoli Silva and Bolli (1973) for the Caribbean section at DSDP Site 152 is clearly present at ODP Site 865 (Fig. 5). The $\mathrm{FAD}$ of $M$. velascoensis is identified at the 132.50 -m horizon, while the $M$. edgari FAD is placed some 27 meters upsection $(105.50 \mathrm{~m})$. It appears that the origination of $M$. edgari ( $\sim 55.60 \mathrm{Ma})$ occurred just prior to the CIE of the late Paleocene thermal maximum and the rapid evolution of a sister species M. allisonensis (see Kelly et al., 1998). The LAD of M. edgari $(94.85 \mathrm{~m})$ is placed some 3 meters above that of $M$. velascoensis $(97.85 \mathrm{~m})$. 
TABLE 1-Chronologic framework for stratigraphic section from ODP Hole 865B. Stratigraphic positions of the FADs of D. multiradiatus and $D$. lodoensis after Bralower and Mutterlose (1995). Core depth of benthic foraminiferal extinction event and carbon-isotope excursion (BFEE-CIE) of the late Paleocene thermal maximum taken from Bralower et al. (1995).

\begin{tabular}{|c|c|c|c|}
\hline $\begin{array}{l}\text { Core } \\
\text { depth } \\
\text { (m) }\end{array}$ & $\mathrm{Ma}$ & Datum & Age ref. \\
\hline 89.60 & 52.85 & D. lodoensis FAD & Berggren et al., 1995 \\
\hline 94.20 & 53.68 & & \\
\hline 94.85 & 5402 & M. edgari LAD & This study \\
\hline 95.70 & 54.20 & & \\
\hline 96.35 & 54.36 & & \\
\hline 96.90 & 54.49 & & \\
\hline 97.35 & 54.59 & & \\
\hline 97.85 & 54.70 & M. velascoensis LAD & Berggren et al., 1995 \\
\hline 98.29 & 54.76 & & \\
\hline 98.60 & 54.81 & & \\
\hline 98.80 & 54.83 & & \\
\hline 99.35 & 54.91 & & \\
\hline 100.20 & 5503 & & \\
\hline 100.70 & 55.10 & & \\
\hline 101.00 & 55.14 & & \\
\hline 102.35 & 55.33 & & \\
\hline 103.60 & 55.50 & BFEE-CIE & Thomas and Shack- \\
\hline 104.20 & 55.54 & & leton, 1995 \\
\hline 105.50 & 55.60 & M. edgari $\mathrm{FAD}$ & \\
\hline 116.21 & 56.20 & D. multiradiatus $\mathrm{FAD}$ & Berggren et al., 1995 \\
\hline 132.50 & 60.00 & M. velascoensis $\mathrm{FAD}$ & Berggren et al., 1995 \\
\hline
\end{tabular}

\section{Compilation of Assemblage Data}

Assemblage counts were performed on the $>250 \mu \mathrm{m}$ (Fig. 6A) and 125 to $250 \mu \mathrm{m}$ (Fig. 6B) sieve-size fractions of each of the samples postdating the CIE. Planktonic foraminifera were classified into four broadly defined groups (Table 2). For comparative purposes, taxa with erratic stratigraphic distributions and consistently low abundances (e.g., various chiloguembelinids, globanomalinids, pseudohastigerinids, and Igorina broedermanni) were grouped under the heading "other." All specimens belonging to the genera Acarinina and Subbotina were grouped accordingly. Morozovellid specimens were classified in either the M. velascoensis lineage or its sister group, the $M$. subbotinae lineage. The $M$. velascoensis group is composed of $M$. acuta, $M$. occlusa, M. velascoensis, and M. edgari; the M. subbotinae group consists of M. apanthesma, M. aequa, M. subbotinae, $M$. gracilis, and $M$. formosa. A minimum of 300 specimens was counted in each sample.

\section{Eigenshape Analysis}

Five sample horizons were selected to summarize the morphological transition, three from the stratigraphic interval predating the $M$. velascoensis LAD (97.85, 98.60, and $102.35 \mathrm{~m}$ ) and two from the interval postdating the $M$. velascoensis $\mathrm{LAD}(95.70$ and $96.35 \mathrm{~m})$. Examination of these planktonic foraminiferal assemblages revealed a preponderance of smaller specimens; size-frequency distributions commonly are skewed in natural populations. Consequently, the five samples were subdivided into a series of size-segregated populations (90-150, 150-250,

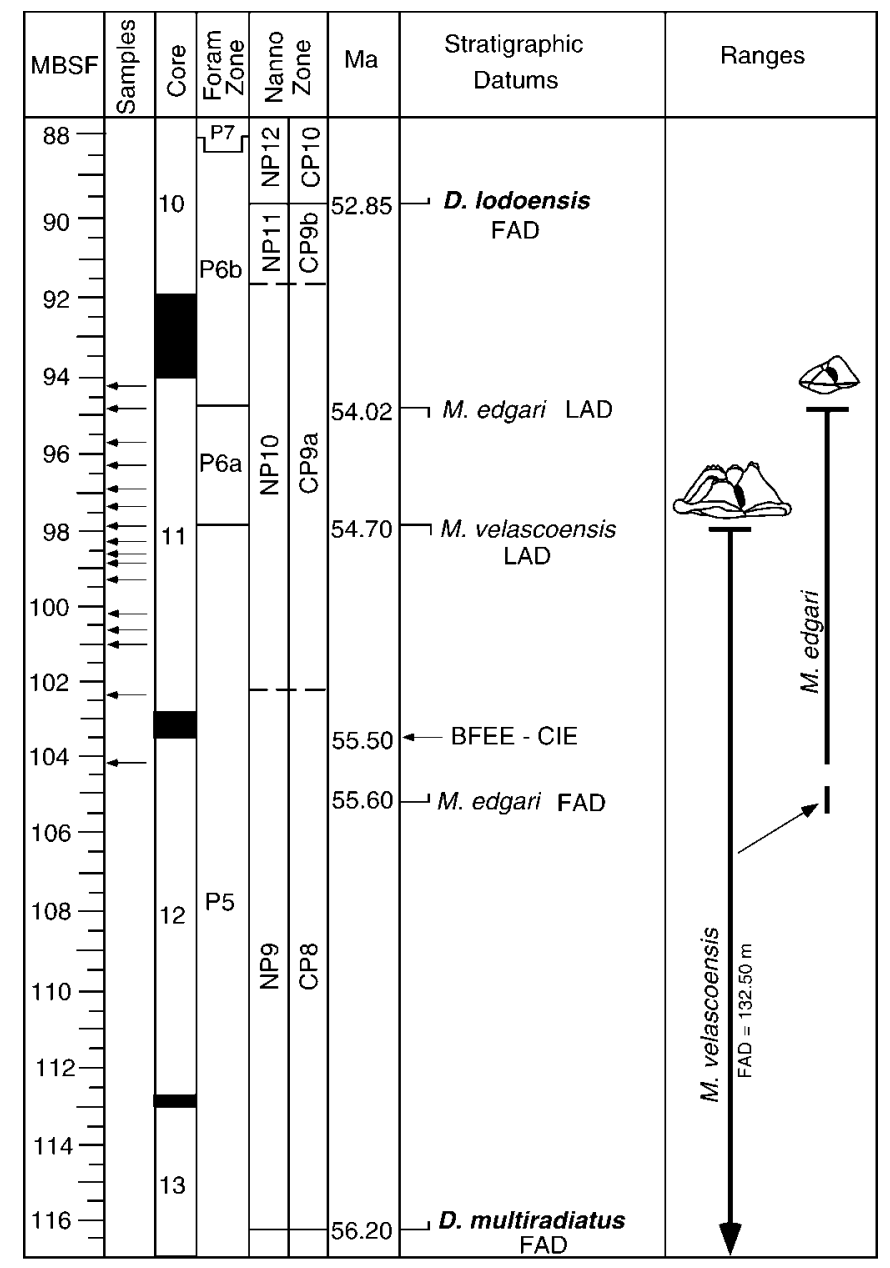

FIGURE 5-Biostratigraphic framework for study section from ODP Hole 865B. BFEE-CIE denotes position of benthic foraminifera extinction event and carbon-isotope excursion of the late Paleocene thermal maximum. Arrows at left signify samples used for assemblage counts. Note first appearance datum (FAD) of Morozovella velascoensis $(132.50 \mathrm{~m})$ is 27 meters downsection from that of $M$. edgari $(105.50 \mathrm{~m})$. LAD $=$ last appearance datum.

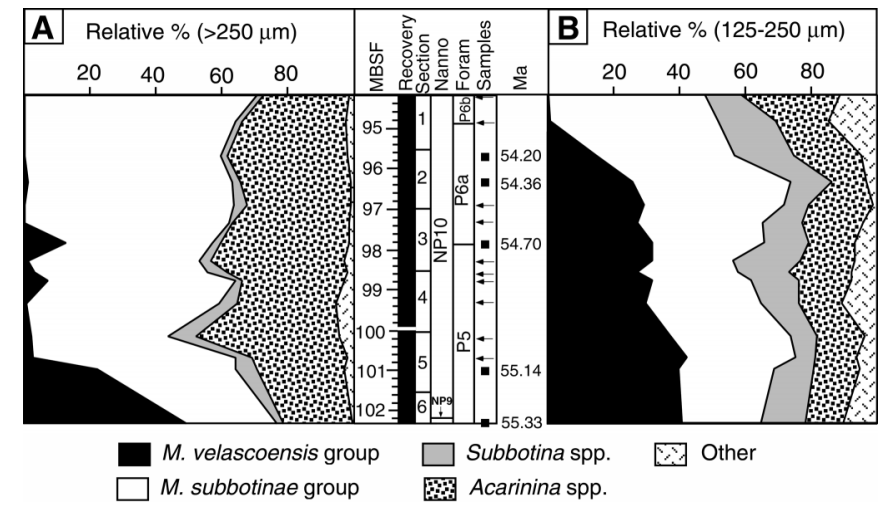

FIGURE 6-Size-dependent, stratigraphic patterns in the relative abundance of the Morozovella velascoensis group. Results of parallel assemblage counts conducted using (A) sieve sizes $>250 \mu \mathrm{m}$ and (B) a sieve size range of $125-250 \mu \mathrm{m}$. Black squares in samples column denote the five stratigraphic samples used for eigenshape analysis. 
TABLE 2-Relative abundance of major groups of planktonic foraminifera during the latest Paleocene and earliest Eocene (Core 11 of ODP Hole 865B). Note that parallel assemblage counts were performed using the $125-250-\mu \mathrm{m}$ and $>250-\mu \mathrm{m}$ sieve-size intervals.

\begin{tabular}{|c|c|c|c|c|c|c|c|c|}
\hline Mbsf & $\mathrm{Ma}$ & Size $(\mu \mathrm{m})$ & $\mathrm{N}$ & $\begin{array}{l}\% M . \\
\text { velascoensis } \\
\text { group }\end{array}$ & $\begin{array}{c}\% M . \\
\text { subbotinae } \\
\text { group }\end{array}$ & $\begin{array}{c}\text { \%ubbotina } \\
\text { sp. }\end{array}$ & $\begin{array}{c}\% \text { Acarinina } \\
\text { sp. }\end{array}$ & $\%$ Other \\
\hline 94.20 & 53.68 & $>250$ & 342 & 0.0 & 70.4 & 1.8 & 26.3 & 1.5 \\
\hline 94.85 & 54.02 & & 321 & 0.0 & 63.9 & 1.9 & 31.4 & 2.8 \\
\hline 95.70 & 54.20 & & 368 & 0.0 & 59.5 & 1.9 & 36.1 & 2.2 \\
\hline 96.35 & 54.36 & & 437 & 0.7 & 62.1 & 2.3 & 33.8 & 1.1 \\
\hline 96.90 & 54.49 & & 317 & 0.0 & 63.4 & 4.1 & 31.9 & 1.3 \\
\hline 97.35 & 54.59 & & 384 & 0.0 & 62.0 & 1.0 & 35.2 & 1.8 \\
\hline 97.85 & 54.70 & & 807 & 12.4 & 44.6 & 2.5 & 38.8 & 1.7 \\
\hline 98.29 & 54.76 & & 322 & 0.9 & 51.7 & 3.5 & 40.8 & 3.1 \\
\hline 98.60 & 54.81 & & 402 & 2.6 & 52.5 & 6.2 & 36.5 & 2.2 \\
\hline 98.80 & 54.83 & & 313 & 6.7 & 56.9 & 2.2 & 31.0 & 3.2 \\
\hline 99.35 & 54.91 & & 379 & 0.5 & 58.3 & 5.6 & 29.8 & 5.8 \\
\hline 100.20 & 55.03 & & 325 & 1.9 & 41.6 & 8.1 & 43.7 & 4.7 \\
\hline 100.70 & 55.10 & & 361 & 2.2 & 61.8 & 5.0 & 28.8 & 2.2 \\
\hline 101.00 & 55.14 & & 434 & 21.9 & 41.8 & 6.7 & 26.5 & 3.1 \\
\hline 102.35 & 55.33 & & 1,202 & 48.9 & 27.4 & 2.1 & 20.8 & 0.8 \\
\hline 94.20 & 53.68 & $125-250$ & 340 & 0.0 & 47.1 & 11.1 & 30.0 & 11.8 \\
\hline 94.85 & 54.02 & & 321 & 0.1 & 51.4 & 17.2 & 16.3 & 15.0 \\
\hline 95.70 & 54.20 & & 448 & 14.3 & 42.0 & 17.9 & 20.5 & 5.4 \\
\hline 96.35 & 54.36 & & 416 & 25.5 & 47.6 & 12.7 & 10.3 & 3.9 \\
\hline 96.90 & 54.49 & & 446 & 28.7 & 42.6 & 7.6 & 19.3 & 1.8 \\
\hline 97.35 & 54.59 & & 324 & 26.9 & 38.0 & 11.7 & 18.8 & 4.9 \\
\hline 97.85 & 54.70 & & 356 & 31.5 & 33.7 & 13.5 & 14.3 & 7.0 \\
\hline 98.29 & 54.76 & & 356 & 31.5 & 24.2 & 20.8 & 16.3 & 7.3 \\
\hline 98.60 & 54.81 & & 486 & 26.9 & 30.6 & 15.5 & 18.8 & 8.2 \\
\hline 98.80 & 54.83 & & 308 & 31.5 & 29.5 & 14.9 & 15.9 & 8.1 \\
\hline 99.35 & 54.91 & & 360 & 29.4 & 34.7 & 11.7 & 13.1 & 11.1 \\
\hline 100.20 & 55.03 & & 332 & 36.8 & 36.5 & 8.1 & 14.5 & 4.2 \\
\hline 100.70 & 55.10 & & 411 & 41.9 & 33.1 & 5.8 & 12.7 & 6.8 \\
\hline 101.00 & 55.14 & & 372 & 39.5 & 29.0 & 11.8 & 14.0 & 5.7 \\
\hline 102.35 & 55.33 & & 495 & 40.0 & 24.0 & 13.3 & 11.7 & 10.5 \\
\hline
\end{tabular}

$250-300,300-355$, and $>355 \mu \mathrm{m})$ and approximately 40 specimens were picked randomly from each sieve-size fraction. This was done to obtain a more uniform representation of the allometry in $M$. velascoensis, although decreases in maximum shell size tended to eliminate the larger size classes in the upper samples.

Morphological variation is best expressed in apertural view (see Figs. 2 and 3). Consequently, the edgewise image of each specimen was captured digitally for eigenshape analysis. The extreme tip of the acute peripheral margin on the final chamber of each silhouette served as a common, relocatable starting point. Only sinistrally-coiled specimens were measured to ensure that the points were digitized in the same sequence; both $M$. velascoensis and M. edgari are typically 95\% sinistrally-coiled (see Bolli, 1957; Premoli Silva and Bolli, 1973).

Following the procedures outlined by Lohmann (1983) and Lohmann and Schweitzer (1990), the digitally recorded points were used to generate 100 equal-length line segments about the perimeter of each silhouette. Outline shapes were then mapped using vectorial data generated by measuring the net angular change at each successive step around the outline perimeter. These vectorial data contain all the information needed to reconstruct the original outline and effectively remove shell-size variation. Finally, the shape data were treated with a modified R-mode principal components analysis to extract a set of orthogonal shape functions, or eigenshape functions (sensu Lohmann, 1983).
Stable Isotope Data

Stable isotope $\left(\delta^{18} \mathrm{O}\right.$ and $\left.\delta^{13} \mathrm{C}\right)$ analyses were performed at the University of California, Santa Cruz, using an Autocarb device coupled to a Fisons Prism gas-source mass spectrometer. Foraminiferal samples were reacted in a common phosphoric acid bath at $90^{\circ} \mathrm{C}$. Average precision for samples smaller than $40 \mu \mathrm{g}$, as determined from replicate analyses of the laboratory standards NBS-19 and Carrera marble, was better than $0.1 \%$ for both $\delta^{18} \mathrm{O}$ and $\delta^{13} \mathrm{C}$ measurements. Samples spanning the transition were divided into six sieve-size classes to detect size-dependent trends in the stable isotopes. Sieve-size intervals and the corresponding number of specimens in each varied as follows: $63-90 \mu \mathrm{m}(50), 90-150 \mu \mathrm{m}$ (35), 150-250 $\mu \mathrm{m}(24), 250-300 \mu \mathrm{m}$ (12). Whenever possible, stable isotope analyses also were performed on individual foraminiferal specimens from the 300-355 and $>355 \mu \mathrm{m}$ sievesize fractions. All measured isotope ratios are reported relative to the Peedee belemnite standard (Appendix 1).

Variation in the stable isotopic signatures of the $M$. velascoensis lineage is evaluated relative to $\delta^{13} \mathrm{C}$ and $\delta^{18} \mathrm{O}$ baselines constructed with the use of two control taxa. Depth-habitats of these control taxa have been characterized with stable isotope ratios (Shackleton et al., 1985; Boersma et al., 1987). One of the control taxa, M. subbotinae, has a relatively low $\delta^{18} \mathrm{O}$ and high $\delta^{13} \mathrm{C}$ composition, reflecting calcification at shallow depths within the oceanic mixed layer (Boersma and Premoli Silva, 1983; 
Shackleton et al., 1985; Boersma et al., 1987). In contrast, the other control group (Subbotina sp.) typically records relatively high $\delta^{18} \mathrm{O}$ and low $\delta^{13} \mathrm{C}$ values and is regarded as having occupied a deeper depth-habitat within the thermocline (Shackleton et al., 1985).

\section{RESULTS}

\section{Planktonic Foraminiferal Assemblages}

Within the $>250-\mu \mathrm{m}$ sieve-size fraction (Fig. 6A), the study lineage is represented by large, ornate forms of $M$. acuta and $M$. velascoensis. These ornate forms are quite common in the lower parts of the study section, but suffer a marked decline in relative abundance further upsection. The relative abundance of the $M$. velascoensis group decreases from $49 \%$ in the lowermost sample $(102.35 \mathrm{~m})$ to nearly $2 \%$ at $100.70 \mathrm{~m}$. After exhibiting a modest recovery in abundance $(12.5 \%$ at $97.85 \mathrm{~m})$, the group suffers its final decline.

In contrast, abundances of the $M$. velascoensis group display a more gradual decline in the smaller (125-250 $\mu \mathrm{m}$ ) sieve-size fraction (Fig. 6B). The extinction of the lineage is recorded at $94.85 \mathrm{~m}, 3$ meters above the extinction observed in the larger $(>250 \mu \mathrm{m})$ sieve-size fraction. Populations of the study lineage consist predominantly of nondescript forms like $M$. edgari within these smaller sievesize fractions. Overall, these findings indicate that the extinction of the $M$. velascoensis group was gradual and entailed a decrease in shell size.

\section{Eigenshape Analysis}

The first eigenfunction explains $59.5 \%$ of the variance and provides a general description of the components of shape that make all the measured outlines similar (e.g., Lohmann and Schweitzer, 1990). The remaining eigenfunctions have captured elements of shape that make each of the outlines different from one another. The second eigenfunction explains $8.5 \%$ of the observed shape variation and is an effective means of expressing the transition from $M$. velascoensis to $M$. edgari. Outlines representative of the entire morphoseries, from $M$. velascoensis to $M$. edgari, are captured by the second eigenfunction. The second eigenfunction describes the degree to which the shoulders of the abaxial margins are umbilically vaulted (Fig. 7). The negative end of the second eigenfunction represents specimen outlines with strongly-vaulted umbilical shoulders due to the presence of a pronounced, pustulate umbilical collar (i.e., $M$. velascoensis). Conversely, the positive end of the second eigenfunction describes outlines that have weakly-vaulted umbilical shoulders and silhouettes that are more biconvex (i.e., M. edgari). Eigenfunctions three through five each explain less than $5 \%$ of the observed variance and display no stratigraphic trends.

Eigenshape analysis of specimens from a series of sizesegregated populations has been shown to be an effective means for studying allometry in modern planktonic foraminifera (Lohmann and Schweitzer, 1990). Thus, a quantitative expression of the allometry in $M$. velascoensis has been obtained by plotting the position (i.e., correlation) of each specimen on the second eigenfunction against its corresponding shell size (Fig. 8). The size of each specimen

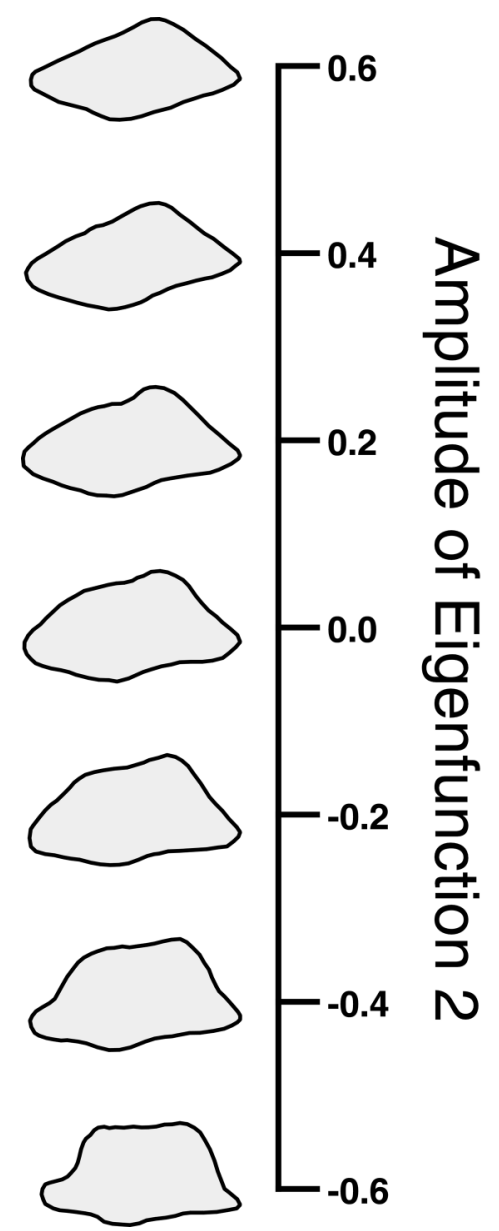

FIGURE 7-Outlines expressing shape variation captured by second eigenfunction. Values along second eigenfunction increase from plano-convex specimens with well-developed umbilical shoulders $(M$. velascoensis) to biconvex forms with poorly-defined umbilical shoulders $(M$. edgari). Plano-convex specimens with strong umbilical shoulders $(M$. velascoensis) have relatively negative values of -0.40 or less, while biconvex forms with poorly-defined umbilical shoulders $(M$. edgari) have values of +0.20 or greater.

was estimated by measuring the diameter of the shell as viewed perpendicular to the coiling axis. Inspection of this allometric plot reveals a logarithmic relationship between shell shape and size $\left(r^{2}=0.601\right.$, d.f. $\left.=625\right)$. The relatively nondescript, biconvex morphologies of $M$. edgari and small $M$. velascoensis are expressed by their relatively positive values along the second eigenfunction. Large $M$. velascoensis with ornate, plano-convex shells tend to have more negative values along the second eigenfunction, although there are a few large $M$. edgari-like variants with positive values. For comparative purposes, outlines of six specimens that plot at different positions along the regression line are illustrated. The somewhat bimodal appearance of the resulting distribution (Fig. 8) is an artifact produced by the irregular sieve-size increments employed to obtain a more uniform representation of the allometry. Thus, while partitioning of the skewed assemblages into a series of size-segregated populations is adequate for expressing the allometry, it should not be taken as a meaningful expression of the relative abundances of different size classes. 


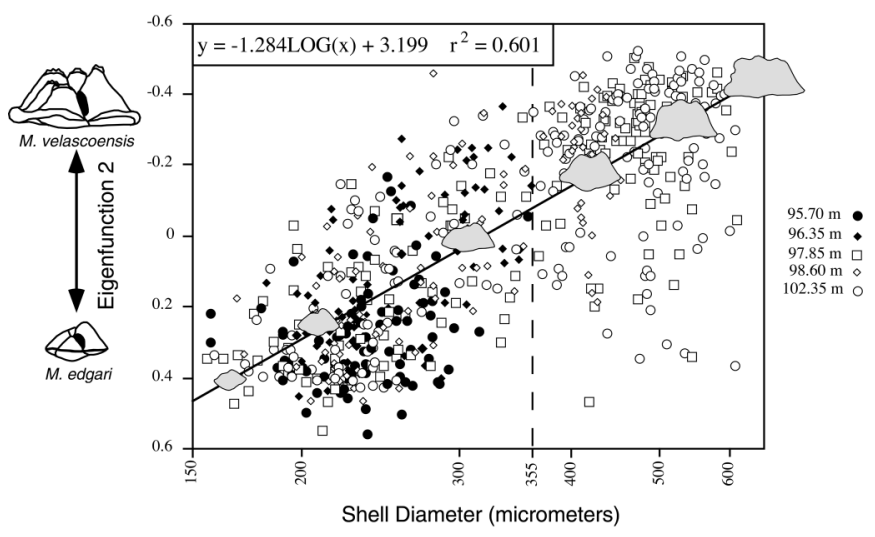

FIGURE 8-Nonlinear relationship between shell size and shape in the Morozovella velascoensis lineage. Allometry graphically depicted by plotting specimen correlations along second eigenfunction against corresponding shell diameter. The composite growth curve is constructed using five different stratigraphic populations. Outlines of six specimens are plotted directly atop allometric trajectory to assist visualization. Note that all specimens from uppermost stratigraphic population $(95.70 \mathrm{~m})$, which postdates the $M$. velascoensis LAD, are smaller than $355 \mu \mathrm{m}$ and have relatively positive correlations (> -0.20 ) along the second eigenfunction.

The morphometric data also show the evolutionary decrease in shell size delineated by the assemblage counts; reduction in maximum shell size is graphically denoted by a $355-\mu \mathrm{m}$ size threshold (Fig. 8). None of the specimens from the two uppermost stratigraphic horizons postdating the $M$. velascoensis $\mathrm{LAD}(96.35 \mathrm{~m}$ and $95.70 \mathrm{~m})$ exceed this size threshold. An ancillary effect of this size reduction is that the population from the uppermost sample $(95.70 \mathrm{~m})$ has an abbreviated allometry. This is indicated by the absence of specimens with values less than -0.20 along the second eigenfunction.

Size-dependent patterns in morphology also are summarized by the succession of shape distributions (Fig. 9). The allometry within each of the five stratigraphic samples is expressed by a negative shift along the second eigenfunction as sieve sizes increase. Specimen outlines representative of the median of each shape distribution are provided to assist with visualization of the allometry (Fig. 9 ). The negative shifts in the shape distributions reflect the change from small $M$. edgari-like morphotypes to larger M. velascoensis forms. The absence of the three largest size fractions $(250-300 \mu \mathrm{m}, 300-355 \mu \mathrm{m},>355 \mu \mathrm{m})$ in the two uppermost samples $(95.70 \mathrm{~m}$ and $96.35 \mathrm{~m})$ is due to the overall decrease in maximum shell size (Fig. 9). Populations in the two uppermost samples consist solely of $M$. edgari and have shape distributions that overlap with

FIGURE 9-Stratigraphic succession of frequency distributions along the second eigenfunction showing size-dependent patterns of shape variation. Each of the five samples is divided into size-segregated populations. The outlines of specimens with median values are shown to the right of each frequency distribution; triangles demarcate position of median for each frequency distribution. Note that, within each sample, the frequency distributions shift from positive values (M. edgarilike) at smaller sieve sizes to more negative values ( $M$. velascoensislike) at larger sieve sizes. Absence of larger sieve-size fractions in some samples is due to decreases in maximum shell size.
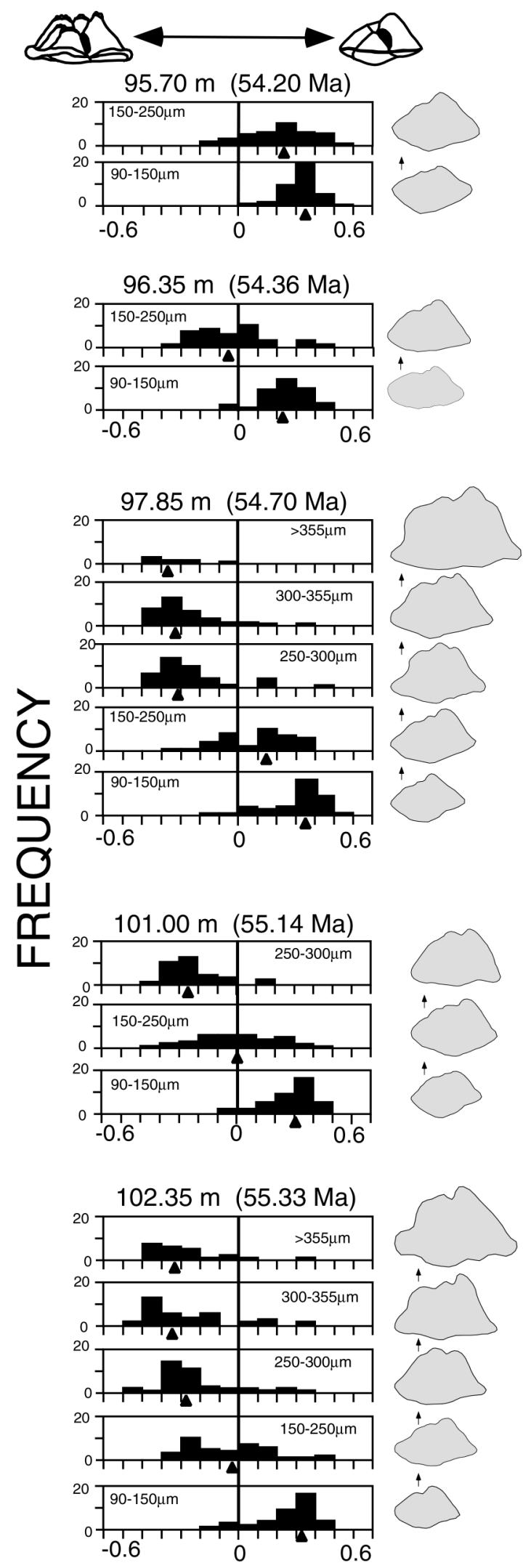

Eigenfunction 2 


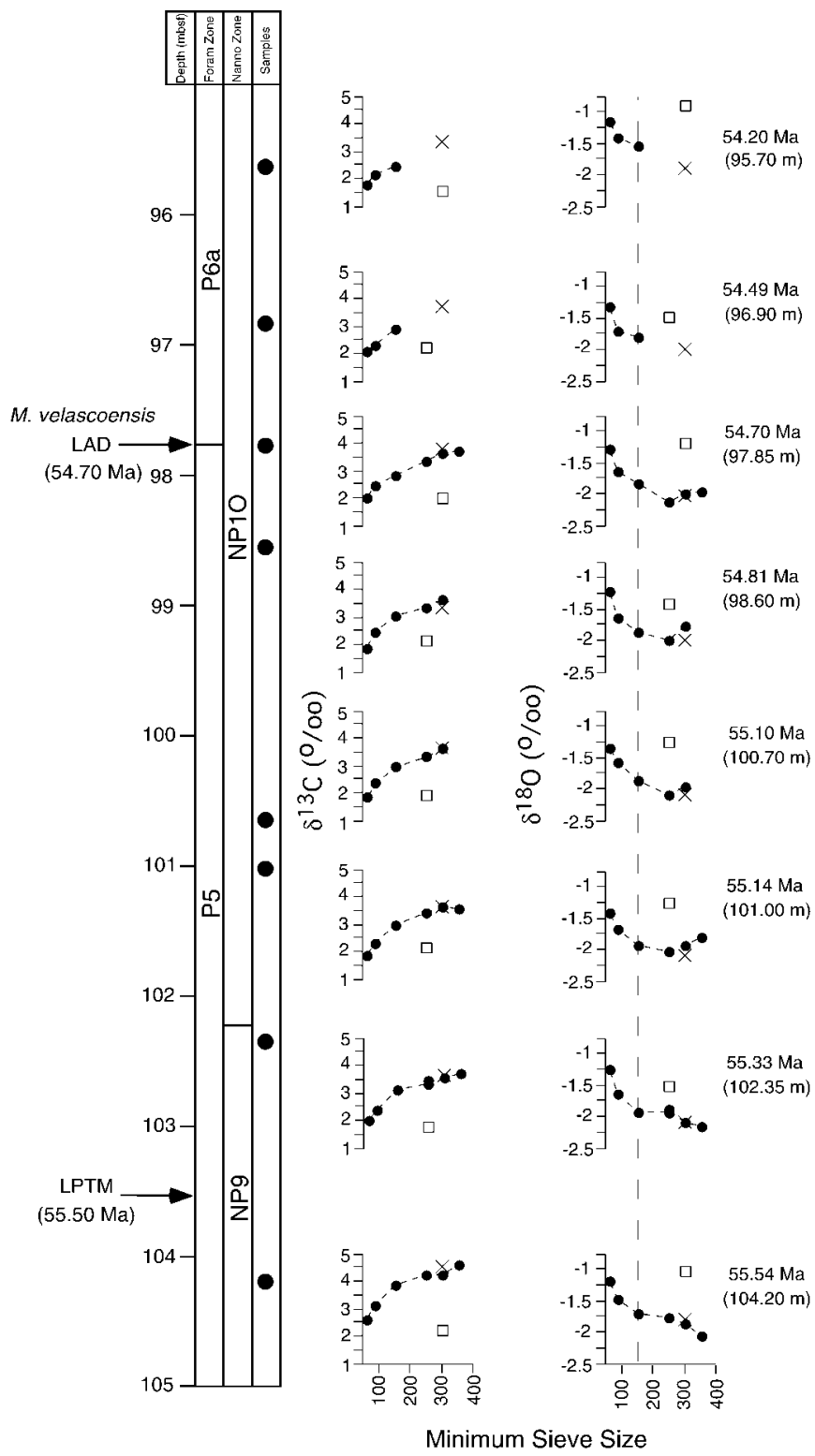

FIGURE 10-Stratigraphic sequence showing size-dependent patterns in carbon (left) and oxygen (right) isotope signatures of $M$. velascoensis and M. edgari at selected sample horizons (see Appendix 1). Only median values are shown for larger sieve-size fractions (300$355 \mu \mathrm{m}$ and $>355 \mu \mathrm{m}$ ), which consist of multiple analyses performed on individual shells. Stable isotope values of a shallow-dwelling taxon, M. subbotinae $(\mathrm{X})$, and a deeper-dwelling genus, Subbotina sp. (open squares), are included for comparison.

those of the smaller size fractions $(90-150 \mu \mathrm{m}$ and 150 $250 \mu \mathrm{m})$ in the three antecedent samples. In fact, the most positive median value for the $150-250-\mu \mathrm{m}$ sieve-size fraction is recorded at the uppermost stratigraphic horizon (54.20 Ma).

\section{Stable Isotope Signatures}

The stable isotope signatures derived from the size-segregated populations of the $M$. velascoensis lineage exhibit a strong size dependency (Fig. 10). In all samples, $\delta^{13} \mathrm{C}$ val- ues covary with shell size, resulting in an average increase of $\sim 1.66 \%$ over the 63 -to-355- $\mu \mathrm{m}$ sieve-size range (Fig. 10, left). The direction and magnitude of the size-dependent $\delta^{13} \mathrm{C}$ shifts are comparable to those reported by other researchers (e.g., Shackleton et al., 1985; D'Hondt et al., 1994; Norris, 1996). In general, the slope of the $\delta^{13} \mathrm{C} /$ size curves exhibits little temporal variation. An exception is the uppermost sample $(95.70 \mathrm{~m})$, where the slope displays a modest decrease. Also, the lowest $\delta^{13} \mathrm{C}$ values for the 90 $150-\mu \mathrm{m}$ and $150-250-\mu \mathrm{m}$ size classes are associated with the diminished slope at $95.70 \mathrm{~m}$. A similar decrease is seen in the corresponding $\delta^{13} \mathrm{C}$ values of the control taxa $S u b$ botina sp. and M. subbotinae. Throughout its stratigraphic range, the carbon isotopic compositions of $M$. velascoensis strongly coincide with those of $M$. subbotinae, being consistently more enriched in ${ }^{13} \mathrm{C}$ relative to comparably-sized Subbotina sp.

Overall, the $\delta^{18} \mathrm{O}$ signatures of $M$. velascoensis and $M$. edgari (Fig. 10, right) are correlated negatively with shell size, a characteristic pattern for this lineage (e.g., Shackleton et al., 1985; D'Hondt et al., 1994; Norris, 1996). The inverse relationship between shell size and $\delta^{18} \mathrm{O}$ ratios is a stratigraphically persistent feature among the smaller sieve-size fractions $(63-250 \mu \mathrm{m})$. The negative correlation between $\delta^{18} \mathrm{O}$ and shell size (Fig. 10, right) results in an average shift of $-0.73 \%$ over the $63-300-\mu \mathrm{m}$ sieve-size intervals. Curiously, $\delta^{18} \mathrm{O}$ values for the $250-300-\mu \mathrm{m}$ sievesize fraction decrease stratigraphically from $-1.78 \%$ o $(104.20 \mathrm{~m})$ to $-2.12 \%$ o $(97.85 \mathrm{~m})$. This tendency towards more negative $\delta^{18} \mathrm{O}$ values in the $250-300-\mu \mathrm{m}$ size class continues upsection until the $\delta^{18} \mathrm{O} /$ size relationship is reversed with respect to the median $\delta^{18} \mathrm{O}$ values of the largest size classes $(>300 \mu \mathrm{m})$.

It also should be noted that the slope of the $\delta^{18} \mathrm{O} / \mathrm{size}$ curve is diminished in the uppermost sample $(95.70 \mathrm{~m})$ where the $\delta^{13} \mathrm{C} /$ size slope decreases. The reduced $\delta^{18} \mathrm{O} /$ size slope is detectable even in the absence of the larger sieve sizes. The reduced $\delta^{18} \mathrm{O} /$ size slope is accompanied by relatively high $\delta^{18} \mathrm{O}$ values for the $63-90-\mu \mathrm{m}, 90-150-\mu \mathrm{m}$, and $150-250-\mu \mathrm{m}$ sieve-size fractions. A similar increase in Subbotina sp. $\delta^{18} \mathrm{O}$ values also is detected at $95.70 \mathrm{~m}$. Overall, however, the Subbotina sp. $\delta^{18} \mathrm{O}$ values are consistently higher than those measured from comparablysized $(>250 \mu \mathrm{m})$ specimens of $M$. velascoensis (Fig. 10, right).

\section{DISCUSSION}

The $M$. velascoensis lineage underwent a marked reduction in shell size during the later stages of its gradual extinction in the tropical Pacific Ocean (ODP Site 865). The largest shell diameters attained by $M$. edgari $(\sim 355 \mu \mathrm{m})$ are only about half the size of the largest shells of ancestral $M$. velascoensis. A similar decrease in shell size has been observed in $M$. edgari populations recovered from DSDP Site 577 in the northern Pacific Ocean (Corfield and Granlund, 1988). In the Caribbean Sea, maximum shell diameters of $M$. edgari also are markedly smaller than $M$. velascoensis (Premoli Silva and Bolli, 1973). Collectively, these observations indicate that the shell-size reduction associated with the extinction of the M. velascoensis lineage was global in its geographic extent.

The stratigraphic decrease in shell size had incidental, 
yet significant, morphological consequences for the transition from $M$. velascoensis to M. edgari. Due to the presence of an allometry in the ancestor, the stratigraphic decrease in size caused adult specimens of the descendant (M. edgari) to be morphologically similar to small specimens of the ancestor ( $M$. velascoensis). This raises the possibility that $M$. edgari may be a subspecific dwarf of $M$. velascoensis, something akin to Huber's (1994) "micromorphs." The biostratigraphic evidence, however, does not support this interpretation. The first appearance datums of the two taxa do not coincide and populations of $M$. edgari are found in stratigraphic horizons postdating the extinction of M. velascoensis by some 680 ky (e.g., Premoli Silva and Bolli, 1973; Norris and Nishi, 2001). Thus, the stratigraphic succession from $M$. velascoensis to M. edgari calls for an alternative explanation, although ecophenotypy undoubtedly contributed to the overall size variation displayed by the lineage.

The smaller size and "juvenile-like" morphology of $M$. edgari adults, particularly those that postdate the LAD of ancestral M. velascoensis, is consistent with a form of paedomorphosis (juvenilization) known as progenesis. Progenesis entails rapid sexual maturation with the concomitant omission of the later developmental stages, stages that would otherwise be expressed in the ancestor (Gould, 1977; McNamara, 1986). Hence, progenesis gives rise to diminutive descendants with adult morphologies that resemble the juvenile stages of their ancestors.

Invoking progenesis to account for the evolution of $M$. edgari is provisional, however, for such an interpretation is predicated upon the assumption that ontogeny, not ecophenotypy, is the primary source of the observed shell-size variation. Ontogenetic studies of modern planktonic foraminifera lend some support to this assumption. Extant species undergo striking physiological changes during growth, and the transformation from one ontogenetic stage to the next is restricted to a limited range of shell sizes (e.g., Bé, 1980; Brummer et al., 1987; Hemleben et al., 1989; Wei et al., 1992). Thus, if shell size is an adequate proxy for estimating ontogenetic age, then the gradual replacement of $M$. velascoensis by $M$. edgari is likely to reflect selection for precocious sexual maturation-progenesis.

Published accounts of size reduction foreshadowing the extinction of other planktonic foraminiferal clades are rare. It is suspected that this lack of documentation is due to the fact that this pattern largely has been overlooked. Possible examples of terminal size reduction within the Paleogene planktonic foraminifera include the late Eocene extinctions of the Globigerinatheka subconglobata/index and Turborotalia cerroazulensis lineages (Toumarkine and Luterbacher, 1985), as well as the early-late Eocene extinction of the genus Acarinina (R. D. Norris, pers. comm., 2000). All three of these Eocene groups display a reduction in shell size within their uppermost stratigraphic occurrences.

Terminal size reduction also can be argued for the Neogene Globorotalia fohsi lineage. Kennett and Srinivasan (1983) have suggested that the diminutive form Globorotalia lenguanesis is a phylogenetic intermediate linking the middle Miocene G. fohsi group to the extant Globorotalia tumida lineage. Subsequent investigations indicate that $G$. lenguanesis indeed is descended from later mem- bers of the G. fohsi lineage (Chaisson and Leckie, 1993), but have called into question the derivation of the G. tumida lineage from G. lenguanesis (Bolli and Sanders, 1985). This latter interpretation has profound phylogenetic implications and, if correct, means that the $G$. fohsi lineage has no extant descendants. Hence, the final 6 my of $G$. fo $h$ si lineage history is represented by a single species, the relatively miniscule $G$. lenguanesis.

Gould (1977) has noted that precocious sexual maturation is a common response among a wide variety of organisms to environmental stress. The stratigraphic pattern of paedomorphosis seen during the gradual extinction of the $M$. velascoensis lineage is similar to that displayed by declining ammonoid families at the close of the Paleozoic Era. The stratigraphically youngest representatives of several Late Paleozoic ammonoid families are paedomorphic genera with anomalously small conch sizes, an evolutionary process referred to as "terminal progenesis" (Glenister and Furnish, 1988).

Documenting examples of terminal size decrease among the planktonic foraminifera is important for three reasons: (1) it establishes the frequency of a stress-induced response that portends extinction; (2) it has potential for extending the longevity of lineages, thereby altering temporal patterns of extinction; and (3) it suggests that small species are more resistant to extinction. In the $M$. velascoensis plexus, recognition of the smaller M. edgari extends the overall duration of the lineage by $\sim 680 \mathrm{ky}$. Moreover, the morphological change associated with the extinction is strikingly different from the classical view that purports the sudden extinction of a large, robust taxon. Should future studies confirm the examples cited above, then micropaleontologists need to incorporate this emergent pattern into their micro- and macroevolutionary views on extinction in the pelagic realm.

\section{Seeking an Extinction Mechanism}

Progenesis can be a powerful vehicle for morphological modification, yet it is only a response; the motor driving evolution is environmental and ecological change. As a consequence, the stable isotope data provide insight into the paleoecology of $M$. velascoensis and the oceanic conditions that triggered the shell-size reduction seen prior to the extinction of this once-dominant lineage.

The stable isotopic signatures of $M$. velascoensis are most analogous to those of modern planktonic foraminifera that inhabit the shallow, mixed layer of the oceans (e.g., Boersma and Premoli Silva, 1983; Shackleton et al., 1985; Boersma et al., 1987; Corfield and Cartlidge, 1991). The relatively negative $\delta^{18} \mathrm{O}$ values of $M$. velascoensis shells reflect calcification within warm, sunlit waters. A shallow depth-habitat also is suggested by the relatively high $\delta^{13} \mathrm{C}$ ratios of $M$. velascoensis; waters within the photic zone often are enriched in ${ }^{13} \mathrm{C}$ due to the preferential uptake of ${ }^{12} \mathrm{C}$ by the photosynthetic activity of phytoplankton.

Furthermore, $M$. velascoensis is one of the more abundant species among tropical and subtropical planktonic foraminiferal assemblages, attesting to its thermophilic affinities (Boersma and Premoli Silva, 1983; Premoli Silva and Boersma, 1989). Ravelo and Fairbanks (1992) also have noted that the reproductive ecologies of modern, 
mixed-layer dwellers are not linked to seasonal changes in hydrography. This reproductive strategy translates to a year-round export of shells to the sea floor, resulting in a dominance of warm water assemblages. Thus, the high relative abundances scored by $M$. velascoensis among tropical planktonic foraminiferal faunas is consistent with its inferred shallow depth-habitat (e.g., van Eijden, 1995; Lu and Keller, 1996).

Establishing that $M$. velascoensis is (1) a predominately tropical species, (2) a shallow-dwelling form that inhabited the photic zone, and (3) a dominant species among warm-water assemblages is important because all of these attributes are shared by modern planktonic foraminifera that host algal symbionts. The pronounced, size-dependent trends seen in the carbon isotopic signatures of $M$. velascoensis (Fig. 10, left) are also consistent with this species having been symbiotic (e.g., D'Hondt et al., 1994; Norris, 1996). Culturing experiments (Spero, 1992; Spero and Lea, 1993) have demonstrated a direct relationship between levels of symbiont photosynthesis and the $\delta^{13} \mathrm{C}$ compositions of planktonic foraminiferal shells. This relationship typically is expressed as a strong $\delta^{13} \mathrm{C} /$ size covariance and is driven by the preferential uptake of ${ }^{12} \mathrm{C}$ by the symbionts (Spero and DeNiro, 1987; Spero and Williams, 1988).

Size-dependent trends of progressive ${ }^{18} \mathrm{O}$-depletion, much like that seen in $M$. velascoensis (Fig. 10, right), also have been observed in modern, symbiotic planktonic foraminifera (Spero and Lea, 1993; Bemis et al., 1998). McConnaughey (1989a, b) has demonstrated that rapid skeletogenesis favors strong kinetic fractionation effects that, in turn, cause biogenic carbonates to become progressively depleted in ${ }^{18} \mathrm{O}$. This being the case, then the relationship between photosymbiosis and size-dependent ${ }^{18} \mathrm{O}$-depletion may be largely incidental.

Comparison of the $\delta^{13} \mathrm{C}$ and $\delta^{18} \mathrm{O}$ values, however, shows that these two size-related patterns do not undergo simultaneous depletions and/or enrichments (Fig. 10). Instead, the two size-dependent signals are related inversely to one another, indicating that processes other than kinetic isotope effects were involved (e.g., McConnaughey, 1989a; D'Hondt et al., 1994; Spero, 1998; Norris, 1998). Thus, when all the evidence is weighed (shallow habitat depth, enhanced calcification, tropical paleobiogeographic range, size-dependent trends of ${ }^{18} \mathrm{O}$-depletion and ${ }^{13} \mathrm{C}$-enrichment), arguments for $M$. velascoensis having hosted algal symbionts become very compelling.

The stratigraphic trend toward reduced shell sizes during the transition from $M$. velascoensis to $M$. edgari is consistent with intra-specific responses seen in modern planktonic foraminifera that have been deprived of algal symbionts. Bé (1982) conducted a series of experiments to test the effects of symbiont elimination on populations of Globigerinoides sacculifer. Despite exhibiting normal vital behavior (e.g., rhizopodial movement, prey capture and digestion), aposymbiotic $G$. sacculifer suffered drastic decreases in growth rates, a response also seen in populations grown in continuous darkness. Of particular interest is the fact that nearly all (98\%) of the aposymbiotic specimens underwent early gametogenesis at relatively small shell sizes. Furthermore, rates of growth and reproduction returned to near normal levels among aposymbiotic specimens reinfected with symbionts. The findings of Bé (1982)
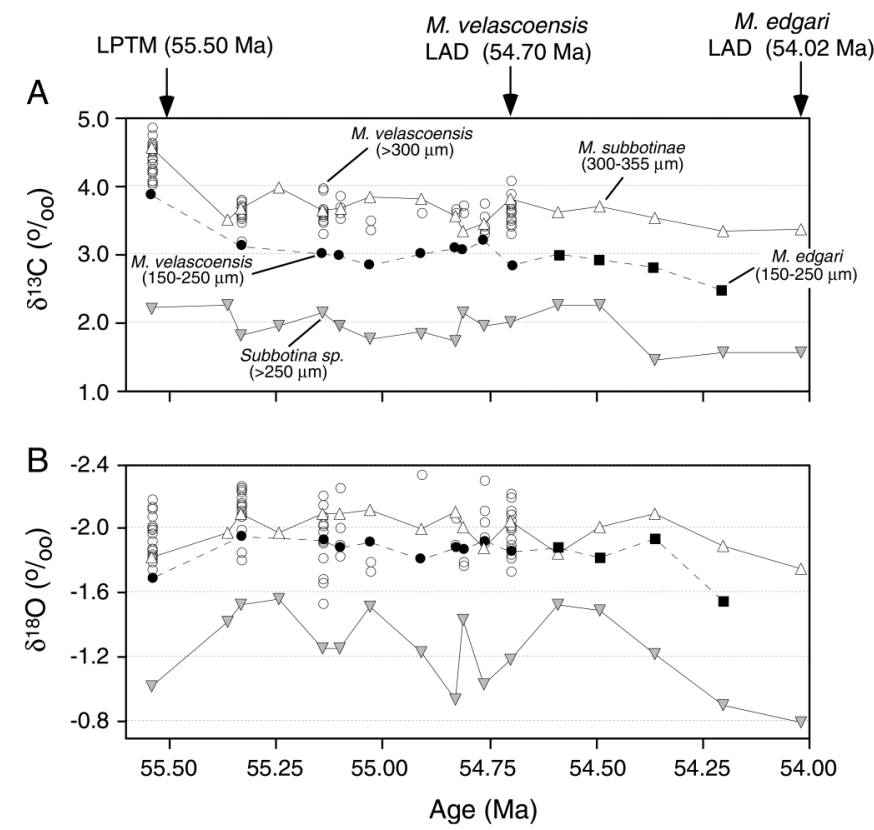

FIGURE 11-Stable isotope stratigraphies spanning the extinction of the $M$. velascoensis lineage at ODP Site 865. Carbon (A) and oxygen (B) isotope stratigraphies for $M$. velascoensis lineage taken from single-specimen $(>300 \mu \mathrm{m})$ and multi-specimen $(150-250 \mu \mathrm{m})$ analyses. For comparison, stable isotopic ratios measured from $M$. subbotinae $(300-355 \mu \mathrm{m})$ and Subbotina sp. $(>250 \mu \mathrm{m})$ are reported. No stable isotope values are reported for uppermost stratigraphic occurrence (54.02 Ma) of $M$. edgari due to diminutive shell sizes and insufficient number of specimens.

demonstrate conclusively that stress caused by symbiont deprivation results in early reproduction and stunted growth.

The observations outlined above lend credence to speculation that the gradual extinction of the $M$. velascoensis group was caused by a progressive deterioration of algal symbiosis. Perhaps subsumed within this long-term decline is a series of multiple environmental changes that caused ancestral populations of $M$. velascoensis to lose their algal symbionts, responses akin to episodes of coral bleaching. The expulsion of symbionts could have triggered early gametogenesis, thereby arresting growth at relatively small shell sizes (e.g., $M$. edgari).

In theory, diminished symbiosis should be evidenced by a decrease in the intensity of the $\delta^{13} \mathrm{C} /$ size covariance and shells of $M$. velascoensis that are depleted relatively in ${ }^{13} \mathrm{C}$. Inspection of the $\delta^{13} \mathrm{C} /$ size curves (Fig. 10, left) reveals no significant slope decreases, and none of the individuallyanalyzed shells record an unusually low $\delta^{13} \mathrm{C}$ value (Fig. 11A). All of the individually-analyzed $M$. velascoensis shells are enriched in ${ }^{13} \mathrm{C}$ relative to their smaller-sized counterparts, as well as to the genus Subbotina sp. (Fig. 11A).

Within the 150-250- $\mu \mathrm{m}$ size classes, M. edgari populations postdating the LAD of $M$. velascoensis (54.70 Ma) exhibit a trend toward lower $\delta^{13} \mathrm{C}$ values (Fig. 11A). However, simultaneous decreases in the $\delta^{13} \mathrm{C}$ values of other coexisting taxa (Subbotina sp. and $M$. subbotinae) suggest that the relatively low $\delta^{13} \mathrm{C}$ values of $M$. edgari reflect secular variation in ocean chemistry, not a breakdown in symbiosis. Moreover, detection of diminished symbiosis is 
hindered by the paucity of $M$. edgari shells in the larger $(>250 \mu \mathrm{m})$ sieve-size fractions. Most planktonic foraminifera, regardless of their ecological affinities, exhibit some degree of $\delta^{13} \mathrm{C} /$ size covariance over the limited size range containing M. edgari (e.g., Berger et al., 1978). It is not until the larger sieve-size fractions that the $\delta^{13} \mathrm{C} /$ size signature of algal symbiosis becomes readily recognizable (see Norris, 1998). Thus, the progenetic size decrease associated with the M. velascoensis/M. edgari transition appears to have thwarted isotopic testing for a collapse of algal symbiosis, although the smaller size of M. edgari is still considered to be a product of stressful conditions.

\section{Did Climatic Cooling in the Earliest Eocene Seal the Extinction of a Declining Lineage?}

The extinction of the $M$. velascoensis lineage, as recorded by the LAD of $M$. edgari at Site $865(\sim 54.02 \mathrm{Ma})$, is roughly correlative with the onset of short-lived, yet substantial, cooling $\left(\sim 7^{\circ} \mathrm{C}\right)$ recorded in early Eocene terrestrial deposits from the North American continental interior (Wing et al., 2000). Additional evidence for short-term cooling in the earliest Eocene ( $\sim 54 \mathrm{Ma})$ has been found among terrestrial palynofloras preserved in parts of northwestern Europe (Beerling and Jolley, 1998). In the Tethyan region, the extinction of M. edgari occurs over an earliest Eocene interval where cool-water taxa become more abundant among the planktonic foraminifera (Pardo et al., 1999). Furthermore, benthic foraminiferal $\delta^{18} \mathrm{O}$ stratigraphies from the South Atlantic and Southern Ocean also show modest temperature decreases at about $54 \mathrm{Ma}$ (Corfield and Norris, 1998). Hence, there is a priori reason to suspect that the demise of the $M$. velascoensis may be linked to climatic cooling.

The assemblage data (Fig. 6A) indicate that the decline of the $M$. velascoensis clade began some $400 \mathrm{ky}$ after the carbon-isotope excursion of the LPTM, with relict populations lingering for another $1 \mathrm{my}$. This stressful period (55.0-54.0 Ma) witnessed not only the extinction of the $M$. velascoensis lineage, but also a major turnover within the calcareous nannoplankton (Aubry, 1998). The global restructuring of the pelagic ecosystem, as evidenced by changes in the calcareous micro- and nannoplankton, indicates that the ocean/climate system varied significantly during the earliest Eocene.

Initially, the stratigraphic reversal seen in the $\delta^{18} \mathrm{O} /$ size relationship among large $(>250 \mu \mathrm{m}) M$. velascoensis was thought to reflect stressed populations that suffered a climatic perturbation to their depth ecology (see Fig. 10, right). Consequently, $\delta^{18} \mathrm{O}$ measurements were performed on individual shells ( $>300 \mu \mathrm{m}$ ) of $M$. velascoensis to detect changes in this species' depth-habitat range. Inspection of the stratigraphic series of single-specimen $\delta^{18} \mathrm{O}$ distributions revealed no stratigraphically meaningful changes in central tendency and/or variance (Fig. 11B). Thus, the cause of the $M$. velascoensis extinction at $54.70 \mathrm{Ma}$ remains unclear.

In horizons postdating the extinction of $M$. velascoensis $(54.70 \mathrm{Ma})$, however, oxygen isotope values measured from the mixed-layer species $M$. subbotinae and the thermocline-dwelling Subbotina sp. display a modest increase (Fig. 11B). Likewise, $\delta^{18} \mathrm{O}$ values measured from M. edgari exhibit a $\sim 0.4 \%$ increase. If all of this isotopic shift is due to temperature change, and not variation in seawater chemistry, then the $\delta^{18} \mathrm{O}$ increase seen at $\sim 54.20 \mathrm{Ma}$ reflects a $\sim 1.5^{\circ} \mathrm{C}$ cooling of tropical surface-waters. The $\delta^{18} \mathrm{O}$ values of $M$. subbotinae and Subbotina sp. continue to increase further upsection over the same stratigraphic interval in which M. edgari last occurs (54.02 Ma). Unfortunately, the diminutive size and scarcity of $M$. edgari shells precluded isotopic measurement of this species at its uppermost stratigraphic level (Fig. 11B). Nevertheless, the oxygen-isotope data indicate that the lineage termination at Site 865 coincided with transient cooling during the earliest Eocene $(\sim 54.02 \mathrm{Ma})$.

\section{SUMMARY AND CONCLUSIONS}

The species Morozovella edgari is estimated to have originated $\sim 55.60 \mathrm{Ma}$ and is the smallest member of the $M$. velascoensis clade. Evolutionary divergence of $M$. edgari from its ancestor, M. velascoensis, entailed a marked decrease in shell size accompanied by a truncation of the ancestral ontogenetic sequence. Omission of later growth stages resulted in paedomorphosis where the adult morphology of the descendant (M. edgari) resembles the juvenile form of the ancestor (M. velascoensis). The coincidence of shell-size reduction and morphological juvenilization suggests that the transition from M. velascoensis to M. edgari was driven by an acceleration in the onset time of reproduction, although this interpretation hinges upon the assumption that shell size is an adequate indicator of ontogenetic age. It is postulated that ancestral populations of M. velascoensis underwent a gradual shift towards precocious sexual reproduction. This, in turn, arrested growth at relatively small shell sizes, ultimately giving rise to diminutive $M$. edgari. In general, the evolutionary series conforms to a paedomorphic process called progenesis.

Subsequent to its origination, $M$. edgari coexisted with its ancestor (M. velascoensis) for nearly $900 \mathrm{ky}$ until the lineage suffered a marked decline at $\sim 54.7 \mathrm{Ma}$. Thus, for reasons still unclear, $M$. edgari became the sole surviving member of this once-dominant lineage. Similar patterns of faunal succession, where relict species of a clade are diminutive paedomorphs, have been observed in other fossil groups; ammonoid workers refer to this process as "terminal progenesis" (Glenister and Furnish, 1988). Moreover, other major clades of planktonic foraminifera may have undergone terminal progenesis prior to extinction. This progenetic process has much potential for extending the longevity of clades, thereby altering stratigraphic patterns of extinction in the pelagic realm.

The gradual decrease in shell size displayed by the $M$. velascoensis clade is considered a response to stressful ecological conditions. The stable isotopic signatures $\left(\delta^{13} \mathrm{C}\right.$ and $\delta^{18} \mathrm{O}$ ) of $M$. velascoensis are most analogous to those of modern planktonic foraminifera that host algal symbionts. Hence, it is speculated that the gradual extinction of the $M$. velascoensis clade was related to a progressive deterioration of symbiosis. Geochemical evidence for a collapse in the symbiotic ecology, namely ${ }^{13} \mathrm{C}$-depleted shells and diminished $\delta^{13} \mathrm{C} /$ size covariances, was not detected. It is possible that isotopic testing was negated by the stratigraphic trend towards smaller shell sizes. Decreasing shell size during the extinction of the $M$. velascoensis clade eliminated the upper portion of the size spectrum where 
the isotopic signature of algal symbiosis is most recognizable.

Oxygen isotope records from a surface-dwelling species (M. subbotinae), a thermocline-dwelling group (Subbotina sp.), and $M$. edgari all display a modest, positive shift $(\sim 0.4 \%$ o over the same stratigraphic interval in which the extinction of $M$. edgari, and termination of the $M$. velascoensis lineage, is recorded $(\sim 54.02 \mathrm{Ma})$. This inferred cooling appears to be correlative with terrestrial records of climatic cooling from the earliest Eocene of the North American continental interior (Wing et al., 2000). Invoking climatic cooling as a factor in the extinction of the cosmopolitan $M$. velascoensis lineage is important because it suggests that imbedded within the early Eocene warm interval is a transient, but geographically-widespread, cooling event.

\section{ACKNOWLEDGEMENTS}

The insightful comments of B. Huber, an anonymous reviewer, and the editorial staff improved this paper. We thank A. Arnold, R. Norris, and P. Pearson for fruitful discussions on various aspects of this research. We also express our gratitude to K. Billups and G. Koehler for technical assistance. Study samples courtesy of the Ocean Drilling Program and I. Premoli Silva. Research supported by National Science Foundation grant EAR 98-14883, Geological Society of America, Carolina Society of Fellows, and a post-doctoral fellowship from Woods Hole Oceanographic Institution.

\section{REFERENCES}

AUBRY, M.P., 1998, Early Paleogene calcareous nannoplankton evolution: A tale of climatic amelioration: in AUBRY, M.P., LUCAS, S.G., and BERGGREN, W.A., eds., Late Paleocene-Early Eocene Climatic and Biotic Events in the Marine and Terrestrial Records: Columbia University Press, New York, p. 158-203.

BÉ, A.W.H., 1980, Gametogenic calcification in a spinose planktonic foraminifera, Globigerinoides sacculifer (Brady): Marine Micropaleontology, v. 5, p. 283-310.

BÉ, A.W.H., 1982, Biology of Planktonic Foraminifera: in BROADHEAD, T.W., ed., Foraminifera: Notes for a Short Course: Studies in Geology 6: The Paleontological Society, p. 51-92.

BEECHER, C.E., 1898, The origin and significance of spines: A study in evolution: American Journal of Science, v. 6, p. 1-20, 125-136, 249-268, 329-359.

Beerling, D.J., and Jolley, D.W., 1998, Fossil plants record an atmospheric ${ }^{12} \mathrm{CO}_{2}$ and temperature spike across the Palaeocene-Eocene transition in NW Europe: Journal of the Geological Society, London, v. 155, p. 591-594.

Bemis, E.B., Spero, H.J., BiJMA, J., and LEA, D.W., 1998, Reevaluation of the oxygen isotopic composition of planktonic foraminifera: Experimental results and revised paleotemperature equations: Paleoceanography, v. 13, p. 150-160.

Berger, W.H., Killingley, J.S., and Vincent, E., 1978, Stable isotopes in deep-sea carbonates: Box core ERDC-92, west equatorial Pacific: Oceanological Acta, v. 1, p. 203-216.

BergGren, W.A., 1968, Phylogenetic and taxonomic problems of some Tertiary planktonic foraminiferal lineages: Tulane Studies of Geology, v. 6, p. 1-22.

BERGGREN, W.A., 1969, Rates of evolution in some Cenozoic planktonic foraminifera: Micropaleontology, v. 15, p. 351-365.

Berggren, W.A., Kent, D.V., Swisher, C.C., III, and Aubry, M.P., 1995, A revised Cenozoic geochronology and chronostratigraphy: in BergGren, W.A., Kent, D.V., Aubry, M.P., and Hardenbol, J., eds., Geochronology, Time Scales and Global Stratigraphic Cor- relation: Society of Economic Paleontologists and Mineralogists, Special Publication No. 54, p.129-212.

BergGren, W.A., and MilleR, K.G., 1988, Paleogene tropical planktonic foraminiferal biostratigraphy and magnetobiochronlogy: Micropaleontology, v. 34, p. 362-380.

BLow, W.H., 1979, The Cainozoic Globigerinida: E. J. Brill, Leiden, $1413 \mathrm{p}$.

Boersma, A., and Premoli Silva, I., 1983, Paleocene planktonic foraminiferal biogeography and the paleoceanography of the Atlantic Ocean: Micropaleontology, v. 29, p. 355-381.

Boersma, A., Premoli Silva, I., and Shackieton, N.J., 1987, Atlantic Eocene planktonic foraminiferal paleohydrographic indicators and stable isotope paleoceanography: Paleoceanography, v. 2, p. 287-331.

BoLLI, H.M., 1957, The genera Globigerina and Globorotalia in the Paleocene-Lower Eocene Lizard Springs Formation of Trinidad, British West Indies: in Loeblich, A.B., Jr., ed., Studies in Foraminifera: United States National Museum Bulletin 215, McLean Paleontological Laboratory, Alexandria, p. 61-81.

BolLI, H.M., and SAUnders, J.B., 1985, Oligocene to Holocene low latitude planktic foraminifera: in Bolli, H.M., SAUNDERS, J.B., and PERCH-NiELSEN, K., eds., Plankton Stratigraphy: Cambridge University Press, Cambridge, p. 155-262.

Bralower, T.J., and MutTERLOSE, J., 1995, Calcareous nannofossil biostratigraphy of Site 865, Allison Guyot, central Pacific Ocean: A tropical Paleogene Reference Section: in WINTERER, E.L., SAGER, W.W., FirTh, J.V., and Sinton, J.M., eds.: Proceedings of the Ocean Drilling Program, Scientific Results, v. 143, p. 31-74.

Bralower, T.J., Zachos, J.C., Thomas, E., PARrow, M., PAull, C.K., Kelly, D.C., Premoli Silva, I., Sliter, W.V., and Lohmann, K.C., 1995, Late Paleocene to Eocene paleoceanography of the equatorial Pacific Ocean: Stable isotopes recorded at Ocean Drilling Program Site 865, Allison Guyot: Paleoceanography, v. 10, p. 841-865.

Brummer, G.J.A., Hemleben, C., and SpINDLER, M., 1987, Ontogeny of extant spinose planktonic foraminifera (Globigerinidae): A concept exemplified by Globigerinoides sacculifer (Brady) and G. ruber (d'Orbigny): Marine Micropaleontology, v. 12, p. 357-381.

Chaisson, W.P., and LECKIE, R.M., 1993, High-resolution Neogene planktonic foraminifer biostratigraphy of Site 806, Ontong Java Plateau (Western Equatorial Pacific): in BERGER, W.H., KROENKE, L.W., MAYER, L.A., et al., Proceedings of the Ocean Drilling Program, Scientific Results, v. 130, p. 137-178.

CORFIELD, R.M., and CARTLIDGE, J.E., 1991, Isotopic evidence for the depth stratification of fossil and Recent Globigerinina: A review: Historical Biology, v. 5, p. 37-63.

CoRFIELD, R.M., and GRANLUND, A.H., 1988, Speciation and structural evolution in the Palaeocene Morozovella lineage (planktonic Foraminiferida): Journal of Micropalaeontology, v. 7, p. 59-72.

CORFIELD, R.M. and NoRRIS, R.D., 1998, The oxygen and carbon isotopic context of the Paleocene/Eocene Epoch boundary: in AUBRY, M.P., LuCAS, S.G., and BERGGREN, W.A., eds., Late PaleoceneEarly Eocene Climatic and Biotic Events in the Marine and Terrestrial Records: Columbia University Press, New York, p. 124137.

D’HondT, S., ZACHOS, J.C., and Schultz, G., 1994, Stable isotopic signals and photosymbiosis in late Paleocene planktonic foraminifera: Paleobiology, v. 20, p. 391-406.

Glenister, B.F., and FuRNish, W.M., 1988, Terminal progenesis in Late Paleozoic ammonoid families: in WiEDMANN, J., and KuLLMANN, J., eds., Cephalopods-Present and Past: Schweizerbart'sche Verlagsbuchhandlung, Stuttgart, p. 51-66.

Gould, S.J., 1977, Ontogeny and Phylogeny: Belknap Press of Harvard University Press, Cambridge, $501 \mathrm{p}$.

Hemleben, C., Spindler, M., and Anderson, O.R., 1989, Modern Planktonic Foraminifera: Springer-Verlag, New York, 363 p.

HUBER, B.T., 1994, Ontogenetic morphometrics of some Late Cretaceous trochospiral planktonic foraminifera from the austral realm: Smithsonian Contributions to Paleobiology No. 77, 85 p.

KElly, D.C., ARNOLD, A.J., and PARKER, W.C., 1996, Paedomorphosis and the origin of the Paleogene planktonic foraminiferal genus Morozovella: Paleobiology, v. 22, p. 266-281.

KELlY, D.C., BRAlOWER, T.J., and ZACHOS, J.C., 1998, Evolutionary 
consequences of the latest Paleocene thermal maximum for tropical planktonic foraminifera: Palaeogeography, Palaeoclimatology, Palaeoecology, v. 141, p. 139-161.

Kelly, D.C., ARNOLD, A.J., and PARKER, W.C., 1999, The influence of heterochrony on the stratigraphic occurrence of Morozovella angulata: Journal of Foraminiferal Research, v. 29, p. 58-68.

KENNETT, J.P., and SRINIVASAN, M.S., 1983, Neogene planktonic foraminifera: A phylogenetic atlas: Hutchinson Ross Publishing Company, Stroudsburg, $265 \mathrm{p}$.

LOHMANN, G.P., 1983, Eigenshape analysis of microfossils: A general morphometric procedure for describing changes in shape: Mathematical Geology, v. 15, p. 659-672.

LoHMANN, G.P., and SchWEITZER, P.N., 1990, On eigenshape analysis: in Rohlf, F.J., and Bookstein, F.L., eds., Proceedings of the Michigan Morphometrics Workshop: Museum of Zoology, University of Michigan, Ann Arbor, p. 147-165.

Lu, G., and KeLLER, G., 1996, Separating ecological assemblages using stable isotope signals: Late Paleocene to early Eocene planktonic foraminifera, DSDP Site 577: Journal of Foraminiferal Research, v. 26, p. 103-112.

LuLL, R.S., 1921, Organic Evolution: MacMillan, New York, 729 p.

McConnaughey, T., $1989 \mathrm{a},{ }^{13} \mathrm{C}$ and ${ }^{18} \mathrm{O}$ isotopic disequilibrium in biological carbonates: I. Patterns: Geochimica et Cosmochimica Acta, v. 53, p. 151-162.

McConnaughey, T., $1989 \mathrm{~b},{ }^{13} \mathrm{C}$ and ${ }^{18} \mathrm{O}$ isotopic disequilibrium in biological carbonates: II. In vitro simulation of kinetic isotope effects: Geochimica et Cosmochimica Acta, v. 53, p. 163-171.

MCNAMARA, K.J., 1986, A guide to the nomenclature of heterochrony: Journal of Paleontology, v. 60, p. 4-13.

NORRIS, R.D., 1996, Symbiosis as an evolutionary innovation in the radiation of Paleocene planktonic foraminifera: Paleobiology, v. 22 , p. 461-480.

NORRIS, R.D., 1998, Recognition and macroevolutionary significance of photosymbiosis in molluscs, corals, and foraminifera: in NoRRIS, R.D., and CoRFIELD, R.M., eds., Isotope Paleobiology and Paleoecology: The Paleontological Society Papers, v. 4, p. 68-100.

NoRRIS, R.D. and NiSHI, H., 2001, Evolutionary trends in coiling of tropical Paleogene planktic foraminifera: Paleobiology, v. 27, p. 327-347.

Olsson, R.K., Hemleben, C., Berggren, W.A., and Huber, B.T., 1999, Atlas of Paleocene planktonic foraminifera: Smithsonian Contributions to Paleobiology No. 85, $252 \mathrm{p}$.

Pardo, A., Keller, G., and Oberhansli, H., 1999, Paleoecologic and paleoceanographic evolution of the Tethyan realm during the $\mathrm{Pa}-$ leocene-Eocene transition: Journal of Foraminiferal Research, v. 29 , p. 37-57.

Premoli Silva, I., and Boersma, A., 1989, Atlantic Paleogene planktonic foraminiferal bioprovincial indices: Marine Micropaleontology, v. 14, p. 357-372.

Premoli Silva, I., and Bolli, H.M., 1973, Late Cretaceous to Eocene planktonic foraminifera and stratigraphy of Leg 15 sites in the Caribbean Sea: in EdGARI, N.T., SAUNDERS, J.B., et al., Initial Reports of the Deep Sea Drilling Project, Volume 15: United States Government Printing Office, Washington, p. 499-547.

RAVELO, A.C., and FAIRBANKS, R.G., 1992, Oxygen isotopic composition of multiple species of planktonic foraminifera: Recorders of the modern photic zone temperature gradient: Paleoceanography, v. 7, p. 815-831.

SAgER, W.W., Winterer, E.L., Firth, J.V., et al., 1993, Proceedings of the Ocean Drilling Program Initial Report 143: College Station, TX (Ocean Drilling Program), 724 p.

Shackleton, N.J., CoRFIELD, R.M., and HALl, M.A., 1985, Stable isotope data and the ontogeny of Paleocene planktonic foraminifera: Journal of Foraminiferal Research, v. 15, p. 321-336.

SPERO, H.J., 1992, Do planktonic foraminifera accurately record shifts in the carbon isotopic composition of seawater $\Sigma \mathrm{CO}_{2}$ ?: Marine Micropaleontology, v. 19, p. 275-285.

SPERO, H.J., 1998, Life history and stable isotope geochemistry of planktonic foraminifera: in NORRIS, R.D., and CORFIELD, R.M., eds., Isotope Paleobiology and Paleoecology: The Paleontological Society Papers, v. 4, p. 7-36.

Spero, H.J., and DeniRo, M.J., 1987, The influence of symbiont photosynthesis on the $\delta^{18} \mathrm{O}$ and $\delta^{13} \mathrm{C}$ values of planktonic foraminiferal shell calcite: Symbiosis, v. 4, p. 213-228.

SPERO, H.J., and LEA, D.W., 1993, Intraspecific stable isotope variability in the planktonic foraminifer Globigerinoides sacculifer: Results from laboratory experiments: Marine Micropaleontology, v. 22, p. 221-234.

SPERO, H.J., and WILliAMS, D.F., 1988, Extracting environmental information from planktonic foraminiferal $\delta^{13} \mathrm{C}$ data: Nature, v. 335 , p. $717-719$.

StAINFORTH, R.M., LAMB, J.L., LuTERBACHER, H., BEARD, J.H., and JEFFORDS, R.M., 1975, Cenozoic planktonic foraminiferal zonation and characteristics of index forms: University of Kansas Paleontological Institute, Article 62: University of Kansas Press, Lawrence, $425 \mathrm{p}$.

Subbotina, N.N., 1971, Fossil foraminifera of the U.S.S.R. (in English): Collet's Publishers Ltd., London, $321 \mathrm{p}$.

SverdLOVE, M.S., and BÉ, A.W.H., 1985, Taxonomic and ecological significance of embryonic and juvenile planktonic foraminifera: Journal of Foraminiferal Research, v. 15, p. 235-241.

Thomas, E., and Shackleton, N.J., 1995, The Paleocene-Eocene benthic foraminiferal extinction and stable isotope anomalies: in Knox, R.W.O'B., CoRfield, R.M., and DunAY, R.E., eds., Correlation of the Early Paleogene in Northwest Europe: Geological Society of London, Special Publication No. 101, p. 401-441.

Toumarkine, M., and LuterbaCHER, H., 1985, Paleocene and Eocene planktic foraminifera: in Bolli, H.M., SAUNDERS, J.B., and Perch-Nielsen, K., eds., Plankton Stratigraphy: Cambridge University Press, Cambridge, p. 87-154.

VAN EIJDEN, A.J.M., 1995, Morphology and relative frequency of planktonic foraminiferal species in relation to oxygen isotopically inferred depth habitats: Palaeogeography, Palaeoclimatology, Palaeoecology, v. 113, p. 267-301.

WeI, K.Y., Zhang, Z.W., and Wray, C., 1992, Shell ontogeny of Globorotalia inflata (I): Growth dynamics and ontogenetic stages: Journal of Foraminiferal Research, v. 22, p. 318-327.

WING, S.L., BAO, H., and KocH, P.L., 2000, An early Eocene cool period? Evidence for continental cooling during the warmest part of the Cenozoic: in Huber, B.T., MacLeod, K.G., and Wing, S.L., eds., Warm Climates in Earth History: Cambridge University Press, Cambridge, p. 197-237.

ACCEPTED MARCH 26, 2001 
APPENDIX 1

Stable Isotope Data

\begin{tabular}{|c|c|c|c|c|c|c|}
\hline Mbsf & Age (Ma) & Taxon & Specimens & Size $(\mu \mathrm{m})$ & $\delta^{13} \mathrm{C}$ & $\delta^{18} \mathrm{O}$ \\
\hline \multirow[t]{2}{*}{94.85} & 5402 & M. subbotinae & 8 & $300-355$ & 3.34 & -1.74 \\
\hline & & Subbotina sp. & 8 & $300-355$ & 1.53 & -0.79 \\
\hline \multirow[t]{5}{*}{95.70} & 54.20 & M. edgari & 50 & $63-90$ & 1.80 & -1.15 \\
\hline & & & 34 & $90-150$ & 2.16 & -1.43 \\
\hline & & & 24 & $150-250$ & 2.42 & -1.55 \\
\hline & & M. subbotinae & 8 & $300-355$ & 3.32 & -1.89 \\
\hline & & Subbotina sp. & 8 & $300-355$ & 1.54 & -0.90 \\
\hline \multirow[t]{3}{*}{96.35} & 54.36 & M. edgari & 25 & $150-250$ & 2.80 & -1.93 \\
\hline & & M. subbotinae & 8 & $300-355$ & 3.52 & -2.09 \\
\hline & & Subbotina sp. & 8 & $300-355$ & 1.43 & -1.21 \\
\hline \multirow[t]{5}{*}{96.90} & 54.49 & M. edgari & 51 & $63-90$ & 2.04 & -1.31 \\
\hline & & & 36 & $90-150$ & 2.32 & -1.69 \\
\hline & & & 25 & $150-250$ & 2.91 & -1.81 \\
\hline & & M. subbotinae & 8 & $300-355$ & 3.67 & -2.00 \\
\hline & & Subbotina sp. & 12 & $250-300$ & 2.25 & -1.48 \\
\hline \multirow[t]{3}{*}{97.35} & 54.59 & M. edgari & 24 & $150-250$ & 3.00 & -1.87 \\
\hline & & M. subbotinae & 8 & $300-355$ & 3.59 & -1.84 \\
\hline & & Subbotina sp. & 12 & $250-300$ & 2.25 & -1.52 \\
\hline \multirow[t]{24}{*}{97.85} & 54.70 & M. velascoensis & 50 & $63-90$ & 2.01 & -1.28 \\
\hline & & & 35 & $90-150$ & 2.45 & -1.63 \\
\hline & & & 24 & $150-250$ & 2.81 & -1.85 \\
\hline & & & 12 & $250-300$ & 3.36 & -2.12 \\
\hline & & & 1 & $300-355$ & 3.63 & -1.90 \\
\hline & & & 1 & $300-355$ & 3.50 & -2.01 \\
\hline & & & 1 & $300-355$ & 3.64 & -2.22 \\
\hline & & & 1 & $300-355$ & 3.66 & -1.99 \\
\hline & & & 1 & $300-355$ & 3.73 & -2.05 \\
\hline & & & 1 & $300-355$ & 3.44 & -1.82 \\
\hline & & & 1 & $300-355$ & 3.30 & -2.11 \\
\hline & & & 1 & $300-355$ & 3.72 & -2.19 \\
\hline & & & 1 & $300-355$ & 3.61 & -1.84 \\
\hline & & & 1 & $300-355$ & 3.61 & -1.93 \\
\hline & & & 1 & $300-355$ & 3.87 & -2.02 \\
\hline & & & 1 & $300-355$ & 3.51 & -2.01 \\
\hline & & & 1 & $300-355$ & 3.41 & -1.73 \\
\hline & & & med. & $300-355$ & 3.61 & -2.01 \\
\hline & & & 1 & $>355$ & 3.74 & -2.09 \\
\hline & & & 1 & $>355$ & 3.73 & -1.88 \\
\hline & & & 1 & $>355$ & 4.06 & -2.09 \\
\hline & & & med. & $>355$ & 3.74 & -1.98 \\
\hline & & M. subbotinae & 8 & $300-355$ & 3.78 & -2.04 \\
\hline & & Subbotina sp. & 8 & $300-355$ & 2.00 & -1.18 \\
\hline \multirow[t]{9}{*}{98.29} & 54.76 & M. velascoensis & 24 & $150-250$ & 3.18 & -1.92 \\
\hline & & & 1 & $300-355$ & 3.54 & -2.04 \\
\hline & & & 1 & $300-355$ & 3.35 & -1.95 \\
\hline & & & 1 & $300-355$ & 3.40 & -2.30 \\
\hline & & & 1 & $300-355$ & 3.28 & -1.91 \\
\hline & & & med. & $300-355$ & 3.38 & -2.00 \\
\hline & & & 1 & $>355$ & 3.73 & -2.11 \\
\hline & & M. subbotinae & 8 & $300-355$ & 3.44 & -1.88 \\
\hline & & Subbotina sp. & 12 & $250-300$ & 1.94 & -1.03 \\
\hline \multirow[t]{9}{*}{98.60} & 54.81 & M. velascoensis & 50 & $63-90$ & 1.88 & -1.22 \\
\hline & & & 35 & $90-150$ & 2.41 & -1.64 \\
\hline & & & 24 & $150-250$ & 3.03 & -1.86 \\
\hline & & & 12 & $250-300$ & 3.37 & -1.99 \\
\hline & & & 1 & $300-355$ & 3.71 & -1.79 \\
\hline & & & 1 & $300-355$ & 3.59 & -1.77 \\
\hline & & & mean & $300-355$ & 3.65 & -1.78 \\
\hline & & M. subbotinae & 8 & $300-355$ & 3.31 & -2.01 \\
\hline & & Subbotina sp. & 12 & $250-300$ & 2.12 & -1.43 \\
\hline \multirow[t]{6}{*}{98.80} & 54.83 & M. velascoensis & 24 & $150-250$ & 3.07 & -1.88 \\
\hline & & & 1 & $300-355$ & 3.66 & -2.06 \\
\hline & & & 1 & $300-355$ & 3.60 & -1.90 \\
\hline & & & mean & $300-355$ & 3.63 & -1.98 \\
\hline & & M. subbotinae & 8 & $300-355$ & 3.53 & -2.10 \\
\hline & & Subbotina sp. & 12 & $250-300$ & 1.71 & -0.93 \\
\hline 99.35 & 54.91 & M. velascoensis & 24 & $150-250$ & 2.99 & -1.80 \\
\hline
\end{tabular}


APPENDIX 1

Continued.

\begin{tabular}{|c|c|c|c|c|c|c|}
\hline Mbsf & Age (Ma) & Taxon & Specimens & Size $(\mu \mathrm{m})$ & $\delta^{13} \mathrm{C}$ & $\delta^{18} \mathrm{O}$ \\
\hline & & & 1 & $300-355$ & 3.61 & -2.34 \\
\hline & & M. subbotinae & 8 & $300-355$ & 3.79 & -1.99 \\
\hline & & Subbotina sp. & 8 & $300-355$ & 1.85 & -1.23 \\
\hline \multirow[t]{6}{*}{100.20} & 55.03 & M. velascoensis & 24 & $150-250$ & 2.83 & -1.91 \\
\hline & & & 1 & $300-355$ & 3.35 & -1.73 \\
\hline & & & 1 & $300-355$ & 3.50 & -1.79 \\
\hline & & & mean & $300-355$ & 3.43 & -1.76 \\
\hline & & M. subbotinae & 8 & $300-355$ & 3.82 & -2.11 \\
\hline & & Subbotinae sp. & 8 & $300-355$ & 1.74 & -1.51 \\
\hline \multirow[t]{11}{*}{100.70} & 55.10 & M. velascoensis & 51 & $63-90$ & 1.87 & -1.34 \\
\hline & & & 35 & $90-150$ & 2.40 & -1.59 \\
\hline & & & 24 & $150-250$ & 2.97 & -1.87 \\
\hline & & & 12 & $250-300$ & 3.37 & -2.10 \\
\hline & & & 1 & $300-355$ & 3.84 & -2.00 \\
\hline & & & 1 & $300-355$ & 3.67 & -1.83 \\
\hline & & & 1 & $300-355$ & 3.59 & -2.25 \\
\hline & & & 1 & $300-355$ & 3.52 & -1.89 \\
\hline & & & med. & $300-355$ & 3.63 & -1.95 \\
\hline & & M. subbotinae & 8 & $300-355$ & 3.65 & -2.09 \\
\hline & & Subbotina sp. & 12 & $250-300$ & 1.93 & -1.25 \\
\hline \multirow[t]{21}{*}{101.00} & 55.14 & M. velascoensis & 52 & $63-90$ & 1.87 & -1.43 \\
\hline & & & 35 & $90-150$ & 2.30 & -1.68 \\
\hline & & & 24 & $150-250$ & 3.00 & -1.92 \\
\hline & & & 12 & $250-300$ & 3.41 & -2.02 \\
\hline & & & 1 & $300-355$ & 3.60 & -1.98 \\
\hline & & & 1 & $300-355$ & 3.50 & -1.82 \\
\hline & & & 1 & $300-355$ & 3.46 & -2.02 \\
\hline & & & 1 & $300-355$ & 3.46 & -1.92 \\
\hline & & & 1 & $300-355$ & 3.92 & -2.21 \\
\hline & & & 1 & $300-355$ & 3.95 & -2.15 \\
\hline & & & 1 & $300-355$ & 3.62 & -1.91 \\
\hline & & & 1 & $300-355$ & 3.65 & -1.66 \\
\hline & & & 1 & $300-355$ & 3.29 & -1.91 \\
\hline & & & 1 & $300-355$ & 3.65 & -1.69 \\
\hline & & & 1 & $300-355$ & 3.55 & -2.03 \\
\hline & & & med. & $300-355$ & 3.60 & -1.92 \\
\hline & & & 1 & $>355$ & 3.58 & -1.53 \\
\hline & & & 1 & $>355$ & 3.56 & -2.08 \\
\hline & & & mean & $>355$ & 3.57 & -1.81 \\
\hline & & M. subbotinae & 8 & $300-355$ & 3.63 & -2.09 \\
\hline & & Subbotina sp. & 12 & $250-300$ & 2.12 & -1.25 \\
\hline \multirow[t]{2}{*}{101.70} & 55.24 & M. subbotinae & 8 & $300-355$ & 3.95 & -1.97 \\
\hline & & Subbotina sp. & 12 & $300-355$ & 1.94 & -1.56 \\
\hline \multirow[t]{24}{*}{102.35} & 55.33 & M. velascoensis & 51 & $63-90$ & 2.03 & -1.26 \\
\hline & & & 35 & $90-150$ & 2.36 & -1.63 \\
\hline & & & 24 & $150-250$ & 3.09 & -1.94 \\
\hline & & & 12 & $250-300$ & 3.35 & -1.93 \\
\hline & & & 12 & $250-300$ & 3.40 & -1.90 \\
\hline & & & 1 & $300-355$ & 3.71 & -2.15 \\
\hline & & & 1 & $300-355$ & 3.57 & -2.07 \\
\hline & & & 1 & $300-355$ & 3.63 & -2.27 \\
\hline & & & 1 & $300-355$ & 3.17 & -1.80 \\
\hline & & & 1 & $300-355$ & 3.80 & -1.99 \\
\hline & & & 1 & $300-355$ & 3.54 & -2.09 \\
\hline & & & 1 & $300-355$ & 3.60 & -2.08 \\
\hline & & & 1 & $300-355$ & 3.54 & -2.23 \\
\hline & & & 1 & $300-355$ & 3.56 & -2.11 \\
\hline & & & 1 & $300-355$ & 3.51 & -2.16 \\
\hline & & & med. & $300-355$ & 3.56 & -2.10 \\
\hline & & & 1 & $>355$ & 3.77 & -2.16 \\
\hline & & & 1 & $>355$ & 3.71 & -2.16 \\
\hline & & & 1 & $>355$ & 3.76 & -2.25 \\
\hline & & & 1 & $>355$ & 3.47 & -2.19 \\
\hline & & & 1 & $>355$ & 3.56 & -2.14 \\
\hline & & & 1 & $>355$ & 3.69 & -1.85 \\
\hline & & & 1 & $>355$ & 3.68 & -2.24 \\
\hline & & & med. & $>355$ & 3.69 & -2.16 \\
\hline
\end{tabular}


APPENDIX 1

Continued.

\begin{tabular}{|c|c|c|c|c|c|c|}
\hline Mbsf & Age (Ma) & Taxon & Specimens & Size $(\mu \mathrm{m})$ & $\delta^{13} \mathrm{C}$ & $\delta^{18} \mathrm{O}$ \\
\hline & & M. subbotinae & 8 & $300-355$ & 3.66 & -2.09 \\
\hline & & Subbotina sp. & 12 & $250-300$ & 1.80 & -1.52 \\
\hline \multirow[t]{2}{*}{102.53} & 55.36 & M. subbotinae & 8 & $300-355$ & 3.48 & -1.97 \\
\hline & & Subbotina sp. & 12 & $250-300$ & 2.24 & -1.42 \\
\hline \multirow[t]{30}{*}{104.20} & 55.54 & M. velascoensis & 50 & $63-90$ & 2.59 & -1.19 \\
\hline & & & 35 & $90-150$ & 3.09 & -1.47 \\
\hline & & & 24 & $150-250$ & 3.85 & -1.69 \\
\hline & & & 12 & $250-300$ & 4.23 & -1.78 \\
\hline & & & 1 & $300-355$ & 4.21 & -1.87 \\
\hline & & & 1 & $300-355$ & 4.19 & -1.99 \\
\hline & & & 1 & $300-355$ & 4.02 & -1.84 \\
\hline & & & 1 & $300-355$ & 4.04 & -1.87 \\
\hline & & & 1 & $300-355$ & 4.51 & -1.82 \\
\hline & & & 1 & $300-355$ & 4.41 & -1.88 \\
\hline & & & 1 & $300-355$ & 4.25 & -1.79 \\
\hline & & & 1 & $300-355$ & 4.33 & -1.97 \\
\hline & & & 1 & $300-355$ & 4.20 & -1.92 \\
\hline & & & 1 & $300-355$ & 4.58 & -1.87 \\
\hline & & & 1 & $300-355$ & 4.38 & -1.86 \\
\hline & & & 1 & $300-355$ & 4.20 & -2.01 \\
\hline & & & 1 & $300-355$ & 4.54 & -1.83 \\
\hline & & & 1 & $300-355$ & 4.08 & -1.82 \\
\hline & & & 1 & $300-355$ & 4.51 & -2.01 \\
\hline & & & med. & $300-355$ & 4.25 & -1.87 \\
\hline & & & 1 & $>355$ & 4.50 & -2.08 \\
\hline & & & 1 & $>355$ & 4.31 & -1.74 \\
\hline & & & 1 & $>355$ & 4.40 & -2.02 \\
\hline & & & 1 & $>355$ & 4.53 & -1.99 \\
\hline & & & 1 & $>355$ & 4.73 & -2.12 \\
\hline & & & 1 & $>355$ & 4.61 & -1.84 \\
\hline & & & 1 & $>355$ & 4.85 & -2.18 \\
\hline & & & med. & $>355$ & 4.62 & -2.05 \\
\hline & & M. subbotinae & 8 & $300-355$ & 4.54 & -1.81 \\
\hline & & Subbotina sp. & 8 & $300-355$ & 2.19 & -1.01 \\
\hline
\end{tabular}

